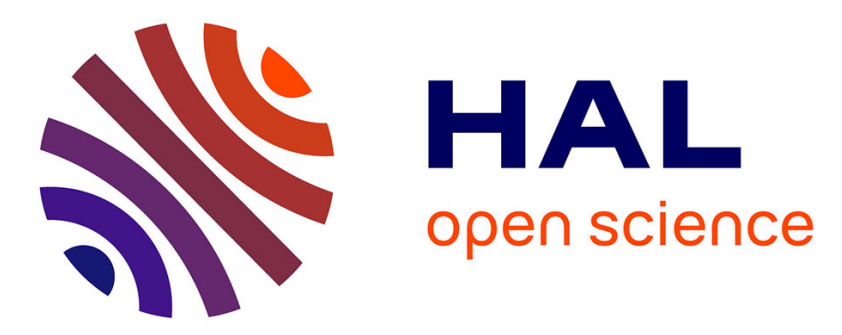

\title{
Bounded by crises: An overview of the evolution of marine ostracods during the Triassic
}

\author{
M.-B. Forel, S. Crasquin
}

\section{To cite this version:}

M.-B. Forel, S. Crasquin. Bounded by crises: An overview of the evolution of marine ostracods during the Triassic. Marine Micropaleontology, 2020, pp.101925. 10.1016/j.marmicro.2020.101925 . hal-02990620

\section{HAL Id: hal-02990620 \\ https://hal.science/hal-02990620}

Submitted on 9 Nov 2020

HAL is a multi-disciplinary open access archive for the deposit and dissemination of scientific research documents, whether they are published or not. The documents may come from teaching and research institutions in France or abroad, or from public or private research centers.
L'archive ouverte pluridisciplinaire HAL, est destinée au dépôt et à la diffusion de documents scientifiques de niveau recherche, publiés ou non, émanant des établissements d'enseignement et de recherche français ou étrangers, des laboratoires publics ou privés. 


\section{Manuscript Details}

\section{Manuscript number}

Title
MARMIC_2020_33

Bounded by crises: an updated view of the evolution of marine ostracods during the Triassic

Research Paper

\section{Article type}

Abstract

The Triassic has been a turning in the history of biodiversity: bracketed by two major biotic crises, characterized by major biotic, climatic and tectonic events, it has seen the transition from the Palaeozoic to the Modern evolutionary faunas. We propose the first synthetic analysis of the diversity of marine and brackish-water ostracods over the entire Triassic, in the light of palaeoecological, palaeoenvironmental and palaeogeographical contexts. Although general diversity trends witness poor ostracod communities during most of the Early Triassic after the end-Permian crisis, the roots of their Triassic taxonomic rediversification are visible as early as the Dienerian. The explosive diversification of the Spathian and Anisian is followed by a high-diversity plateau up to the brink of the end-Triassic extinction. A "morphological phylogeny" proposes that all Permian and Triassic ornate Bairdiidae derived from Petasobairdia in the Kungurian, with the emergence of the Ceratobairdia-lineage and Abrobairdia-lineage. While they are generally the "poor cousin" of trophic chains analyses, traces of typical Mesozoic drilling predation on Late Triassic ostracods unexpectedly document the increase of the efficiency of predators drilling abilities through the Triassic. Finally, the palaeogeographical distribution of ostracods as been very dynamic during this interval, with distinct peri-palaeotethyan and peri-neo-tethyan biotas in the Early Triassic, followed by a dispersal and thus a relative homogenization from the Anisian onwards.

\section{Keywords}

\section{Manuscript region of origin}

Corresponding Author

\section{Corresponding Author's Institution}

\section{Order of Authors}

Suggested reviewers
Ostracods; Early, Middle, Late Triassic; Diversity; Palaeogeography; Ornate Bairdiidae

Europe

Marie-Beatrice Forel

Muséum national d'Histoire naturelle

Marie-Beatrice Forel, Sylvie Crasquin

Avraham Honigstein, Maria Cristina Cabral, Alan Lord, Emöke Tóth 


\section{Submission Files Included in this PDF}

\section{File Name [File Type]}

Forel \& Crasquin COVER LETTER.docx [Cover Letter]

Forel \& Crasquin HIGHLIGHTS.docx [Highlights]

Forel \& Crasquin ABSTRACT.docx [Abstract]

Forel \& Crasquin.docx [Manuscript File]

Forel \& Crasquin FIGURE 1.pdf [Figure]

Forel \& Crasquin FIGURE 2.pdf [Figure]

Forel \& Crasquin FIGURE 3.pdf [Figure]

Forel \& Crasquin FIGURE 4.pdf [Figure]

Forel \& Crasquin FIGURE 5.pdf [Figure]

Forel \& Crasquin FIGURE 6.pdf [Figure]

Forel \& Crasquin FIGURE 7.pdf [Figure]

Forel \& Crasquin FIGURE 8.pdf [Figure]

Forel \& Crasquin FIGURE 9.pdf [Figure]

declaration-of-competing-interests.docx [Conflict of Interest]

\section{Submission Files Not Included in this PDF}

\section{File Name [File Type]}

Forel \& Crasquin TABLE 1.xIs [Table]

Supplementary File 1.xlsx [Supplementary Material]

Supplementary File 2.xlsx [Supplementary Material]

To view all the submission files, including those not included in the PDF, click on the manuscript title on your EVISE Homepage, then click 'Download zip file'.

\section{Research Data Related to this Submission}

There are no linked research data sets for this submission. The following reason is given: These data correspond to the 2 supplementary files that accompany the manuscript 
Dr. Marie-Béatrice Forel

Associate Professor

CR2P - Origins and Evolution department

Muséum national d'Histoire naturelle

Paris, France

Paris, April 20, 2020

\section{Dear Editor,}

Please found here the manuscript entitled 'Bounded by crises: an updated view of the evolution of marine ostracods during the Triassic' (Forel M.-B. \& Crasquin S.) we would like to propose for publication in Marine Micropaleontology, for the Ostracoda special issue edited by M. Yasuhara.

This contribution is the first review of the diversity of marine and brackish-water ostracods during the Triassic, a major period in the history of biodiversity worldwide. Thanks to a large database of all ostracod taxa documented during this interval, we describe their diversity from assemblages recovering from the end-Permian extinction to those going extinct at the end of the Triassic. We summarize and discuss their characteristics, importance to reconstruct the early roots of the Mesozoic marine revolution and describe their geographic distribution through time. Finally, we propose a phylogeny of ornate Bairdiidae that display a still challenging explosive diversification during this interval.

On behalf of my collaborator, thank you for giving this work your consideration. 
Highlights

- Explosive diversification of ostracods during the Spathian and Anisian, Triassic.

- Ornate Bairdiidae derived from Petasobairdia in the Kungurian.

- Ostracods show increasing drilling abilities of Triassic predators.

- Homogenization of geographical distribution from the Anisian onwards. 
The Triassic has been a turning in the history of biodiversity: bracketed by two major biotic crises, characterized by major biotic, climatic and tectonic events, it has seen the transition from the Palaeozoic to the Modern evolutionary faunas. We propose the first synthetic analysis of the diversity of marine and brackish-water ostracods over the entire Triassic, in the light of palaeoecological, palaeoenvironmental and palaeogeographical contexts. Although general diversity trends witness poor ostracod communities during most of the Early Triassic after the end-Permian crisis, the roots of their Triassic taxonomic rediversification are visible as early as the Dienerian. The explosive diversification of the Spathian and Anisian is followed by a high-diversity plateau up to the brink of the endTriassic extinction. A "morphological phylogeny" proposes that all Permian and Triassic ornate Bairdiidae derived from Petasobairdia in the Kungurian, with the emergence of the Ceratobairdia-lineage and Abrobairdia-lineage. While they are generally the "poor cousin" of trophic chains analyses, traces of typical Mesozoic drilling predation on Late Triassic ostracods unexpectedly document the increase of the efficiency of predators drilling abilities through the Triassic. Finally, the palaeogeographical distribution of ostracods as been very dynamic during this interval, with distinct peri-palaeo-tethyan and peri-neo-tethyan biotas in the Early Triassic, followed by a dispersal and thus a relative homogenization from the Anisian onwards.

\section{Keywords:}

Ostracods

Early, Middle, Late Triassic

Diversity

Palaeogeography

Ornate Bairdiidae 


\title{
Bounded by crises: an updated view of the evolution of
} marine ostracods during the Triassic

\author{
M.-B. Forela, ${ }^{*}$, S. Crasquina \\ ${ }^{a}$ CR2P, MNHN-CNRS-SU, 8 rue Buffon (CP38), 75005 Paris, France \\ ${ }^{*}$ Corresponding author at: Muséum national d'Histoire naturelle, CR2P, MNHN-CNRS-SU, 8 rue Buffon (CP38), 75005 Paris, \\ France. \\ E-mail address: marie-beatrice.forel@mnhn.fr (M.-B. Forel).
}

\section{ABSTRACT}

The Triassic has been a turning in the history of biodiversity: bracketed by two major biotic crises, characterized by major biotic, climatic and tectonic events, it has seen the transition from the Palaeozoic to the Modern evolutionary faunas. We propose the first synthetic analysis of the diversity of marine and brackish-water ostracods over the entire Triassic, in the light of palaeoecological, palaeoenvironmental and palaeogeographical contexts. Although general diversity trends witness poor ostracod communities during most of the Early Triassic after the end-Permian crisis, the roots of their Triassic taxonomic rediversification are visible as early as the Dienerian. The explosive diversification of the Spathian and Anisian is followed by a high-diversity plateau up to the brink of the endTriassic extinction. A "morphological phylogeny" proposes that all Permian and Triassic ornate Bairdiidae derived from Petasobairdia in the Kungurian, with the emergence of the Ceratobairdia-lineage and Abrobairdia-lineage. While they are generally the "poor cousin" of trophic chains analyses, traces of typical Mesozoic drilling predation on Late Triassic ostracods unexpectedly document the increase of the efficiency of predators drilling abilities through the Triassic. Finally, the palaeogeographical distribution of ostracods as been very dynamic during this interval, with distinct peri-palaeo-tethyan and peri-neo-tethyan biotas in 
the Early Triassic, followed by a dispersal and thus a relative homogenization from the Anisian onwards.

Keywords:

Ostracods

Early, Middle, Late Triassic

Diversity

Palaeogeography

Ornate Bairdiidae 


\section{Introduction}

The end-Permian extinction (EPE), 252 Ma (Burgess et al., 2014; Baresel et al., 2017), has been the largest biological crisis in Earth's history, with the extinction of more than $90 \%$ of marine species (e.g., Raup, 1979; Erwin, 1994; Alroy et al., 2008; Stanley, 2016). The emission of the Siberian continental flood basalts is currently considered as the main trigger for the crisis, and the associated release of aerosols and/or $\mathrm{CO}_{2}$ and their feedbacks on oceanic and terrestrial systems may have intensified its environmental and ecological stresses (e.g., Campbell et al., 1992; Renne et al., 1995; Reichow et al., 2009; Saunders and Reichow, 2009). The Triassic is one of the most significant intervals of time in the history of biodiversity with the stepwise restauration of land and sea ecosystems after the EPE, the rise of the modern fauna and the emergence of modern ecosystems (e.g., Sepkoski, 1984; Brusatte et al., 2010; Chen and Benton, 2012; Benton et al., 2013). Most of the new predators that have been later involved in the Mesozoic marine revolution (Vermeij, 1977), such as predatory gastropods, decapods, neopterygian fishes and marine reptiles, were already established in the Triassic (e.g., Chen and Benton, 2012 and references therein for a review). Middle and Late Triassic drill holes on mollusks and brachiopods (Klompmaker et al., 2016; Tackett and Tintori, 2019) document the establishment of a typical Mesozoic drilling activity early in the Mesozoic and thus the rooting of the Mesozoic marine revolution deep into the Triassic.

Marine ostracods have been documented through the entire Permian and Triassic systems worldwide (e.g., Wang, 1978; Chen and Shi, 1982; Shi and Chen, 1987; Yi, 1992; Hao, 1994; Crasquin-Soleau et al., 2006; Yuan et al., 2007, 2009; Mette, 2008, 2010; Crasquin et al., 2010; Forel and Crasquin, 2011a, b; Forel et al., 2013a, b, 2015, 2019a, b; Forel, 2012, 2014). They went through severe losses and a deep restructuration of their communities through the EPE (Crasquin-Soleau et al., 2007; Crasquin and Forel, 2014 for review). The Triassic period has also been of paramount importance in the macroevolution for ostracods, 


\section{A brief state of the art}

\subsection{Ostracods through the end-Permian extinction}

Marine ostracods greatly suffered from the EPE, with a species extinction rate of about $80 \%$ (Crasquin and Forel, 2014). Several species spanning the Permian document continuous environmental stress over this interval, as revealed by substantial reduction of the body size and growth rates that culminated at the EPE (Forel et al., 2015). The EPE was peculiarly a major strike for taxa such as Palaeocopida that were widespread and diverse during the 
entire Palaeozoic in both neritic and deep waters (e.g., Kozur, 1985; Becker and Wang, 1992) but barely survived until their last known occurrence at the beginning of the Late Triassic (Carnian; Forel et al., 2019a).

Distinct recovery phases have been described for ostracod assemblages in the Early and Middle Triassic (Fig. 1A). Diverse types of ostracod survival have been reported from the survival phase, directly after the EPE (Early Triassic, Griesbachian). A short-lived survival of abundant Bairdiidae is associated with post-extinction microbial mats thriving around the Palaeo-Tethys, that were exploited for $\mathrm{O}_{2}$ and food resources (Forel et al., 2009, 2013a, b, 2015; Forel, 2012, 2014; Hautmann et al., 2015; Martindale et al., 2019). Bairdiidae are traditionally considered as restricted to stable and normal marine water bodies (e.g., Melnyk and Maddocks, 1988) but these post-EPE assemblages challenge this paradigm in illustrating unexpected adaptive faculties including modifications of reproduction, growth rates and body sizes (Forel, 2014; Forel et al., 2013a, b, 2015; Forel, 2018). The second type is the abundant survivorship of Hollinellidae (Palaeocopida) in very proximal clastic zones, under the influence of high detrital input that has, to date, only been reported from Vietnam (Crasquin et al., 2018) and South China (Forel et al., under review). The last survival type is that of abundant Cavellinidae only observed from northwest Iran (Gliwa et al., 2020) and that is currently under description. These diverse patterns highlight the necessity of shifting paradigm from a unique phenomenon to a wide range of survivals that need to be considered in their entire taxonomic and environmental complexities (Forel et al., under review). Following this period of survival, the Dienerian and Smithian interval yielded very rare ostracods worldwide, earning it the name of maximum of poverty (Crasquin-Soleau et al., 2007; Crasquin and Forel, 2014). The recovery of ostracods is considered as complete in the Anisian, Middle Triassic (Crasquin and Forel, 2014).

Our current knowledge is therefore quite detailed regarding the biodiversity characteristics of ostracods through the extinction and to the Anisian, during which the full recovery of the assemblages is assumed to have occurred. However, this Early-Middle Triassic dynamic has, until now, never been discussed in the light of palaeogeographical and 
palaeoenvironmental conditions, and never been replaced in the context of the entire Triassic. The Triassic is of crucial importance in the history of biodiversity as it was bounded by two of the five major extinctions of the Phanerozoic. However, global understanding of the diversity and evolution of ostracods during the Late Triassic, at the brink of the end-Triassic crisis, is still lacking. Many questions are still pending and in the context of increasing proofs of Mesozoic marine revolution being rooted down to the Triassic, what new information ostracods may provide?

\subsection{The Triassic}

The Triassic period lasted from 252 to $201 \mathrm{Ma}$ (Cohen et al., 2013, updated version 2020; Fig. 1A) and was bracketed by two major biological crises. It has been critical in the origin of marine and continental modern ecosystems, with the origin of key vertebrates including dinosaurs (e.g., Brusatte et al., 2010), frogs, turtles, rhynchocephalians, crocodilomorphs and mammals (Benton 2016 and references thereine for a review). In the Triassic, all continents were fused into the supercontinent Pangaea, incised on its eastern by the Tethys forming a large embayment side and surrounded by the Panthalassa Ocean that covered more than $70 \%$ of Earth's surface (Fig. 1B). The fragmentation of the Pangaea began near the end of the Triassic with the outpouring of the massive Central Atlantic magmatic province (e.g., Marzoli et al., 1999; Davies et al., 2017). Triassic climates were warm and equable, with no polar icecaps. In the Early-Middle Triassic, the sea level was similar to or $10-20 \mathrm{~m}$ higher than the present-day mean sea level. An important rise occurred at the end of the Ladinian and culminated in the late Carnian, representing the highest Triassic sea level ( $\sim 0$ m above present-day mean sea level). The late Norian recorded a decline, followed by stable levels close to present-day until the mid-Rhaetian when the decline further accentuated to about $50 \mathrm{~m}$ below present-day in the latest Triassic and earliest Jurassic (Haq, 2018).

The Triassic has been marked by two major events. The first one, at the Smithian-Spathian boundary, is generally considered as the most significant event within the post-EPE recovery 


\section{Methods}

\subsection{Data}

For the present analysis, all Triassic occurrences of marine and brackish ostracod genera were gathered from the literature and our own data (the complete literature list is given in Supplementary File 1). For each occurrence, we provide palaeogeographical and stratigraphic information at the stage level that were eventually updated from additional literature and Palaeobiology Database (accessed in March 2020). Following the taxonomic 
harmonization described below, one hundred seventy-six genera distributed into forty-one families span from the Griesbachian (Early Triassic) to the Rhaetian (Late Triassic) (Table 1). Genera reported from the "Early Triassic", "Middle Triassic" or "Late Triassic" have been considered as occurring during all stages of the epoch considered: Judahella (Early Triassic, Tunisia; Kamoun et al., 1994); Simeonella (Early Triassic, China; Wei et al., 1983); Cavellina and Liuzhinia (Middle Triassic, China; Wei et al., 1983); Gombasekella (Middle Triassic, India; Agarwal, 1992); Cypridina (Middle Triassic, Bosnia and Italy; Late Triassic, Brasil; Kornicker et al., 2006); Cytherella, Fabanella, Hungarella (Late Triassic, Iraq; Al-Khahab and Al-Halawachi, 2018). Conversely, Triadocypris reported from the Triassic of Vietnam (Kornicker et al., 2006) was not considered because of this large age uncertainty.

\subsection{Taxonomic harmonization}

The classification of Triassic Cytheruridae follows the revisions of Whatley and Boomer (2000), that of Limnocytheridae follows Whatley and Moguilevsky (1998) and the classification of Bythocytheridae follows Schornikov $(1988,1990)$. Punciidae are attributed to the Punciocopida following Danielopol and Swanson (2019) rather than to Palaeocopida (e.g., Horne et al., 2002).

For the present investigation, the following generic adjustments have been necessary. Polycopsis Müller, 1894 was erected based on modern material mainly using soft body characters and several authors pointed out the impossibility to distinguish between Polycope Sars, 1866 and Polycopsis in the absence of soft parts (e.g., Urlichs, 1972; Neale, 1983). We follow Urlichs (1972) and subsequent authors as Kolar-Jurkovšek (1990), Monostori and Tóth (2013), Sebe et al. (2013), Forel and Moix (in press) in considering that Triassic reports of Polycopsis are unreliable. Polycopsis species in Kozur (1970), Bunza and Kozur (1971), Kozur et al. (2000) are therefore re-attributed to Polycope.

The classification of Triassic Healdiidae and Bairdiidae still problematic but it is beyond the scope of this paper to attempt a revision of these major ostracod groups. The original 
classification of Triassic ornate bairdiids proposed by Kollmann $(1960,1963)$ is thus followed in considering the primary ornamentation as relevant generic character. Triebelina van den Bold, 1946 was also described from modern material and its affinities to other present-days bairdiids is complex, as shown by discussion in Maddocks and Wouters (1991) and by the different opinions on its synonymy with Glyptobairdia Stephenson, 1946 summarized in Malz and Lord (1988). Because of the high level of homeomorphy in ornate Bairdiidae (e.g. Maddocks and Wouters, 1991), Triassic occurrences of Triebelina are not considered as valid (e.g., Bolz 1971a, b; Urlichs, 1972; Dépêche and Crasquin-Soleau, 1992) and are here re-attributed to their respective subgeneric identifications.

For the phylogenetic analysis of Permian the Triassic ornate Bairdiidae we perform, Lanczichebairdia Gramm, 1997 and Arcibairdia Gramm, 1997 from the Capitanian of USSR (Gramm, 1997) are considered respectively as junior synonyms of Petasobairdia Chen in Chen and Shi, 1982 and Bairdiolites Croneis and Gale, 1939. Praelobobairdia Kozur, 1985 is considered as a junior synonym of Petasobairdia, following Becker (2001). Following Becker (2001), the smooth bairdiid Rectobairdia Sohn, 1960 and Cryptobairdia Sohn, 1960 are considered as subgenera of Bairdia McCoy, 1844.

The possible synonymy of the Healdiidae Ogmoconcha Triebel, 1941 and Hungarella (Méhes, 1911) has long been debated. Here we follow Kristan-Tollmann (1977a, b), Lord (1982), Boomer and Jellinek (1996), among others, in considering this synonymy as unlikely given the distinct central muscle scar field patterns observed in these genera. We also follow Lord (1972) in considering that until the relationship of Ogmoconcha and Hungarella is clarified, Hungarella should only been used for Triassic species to avoid artificially rooting Ogmoconcha down to the Triassic. Morphologically, the left and right valves of Hungarella are asymmetrical contrary to those of Ogmoconcha (Kristan-Tollmann, 1977a, b; Lord, 1982): in the absence of observable central muscle scars, all Triassic occurrences of Ogmoconcha and Ogmoconchella are here re-attributed to the genus Hungarella.

\section{Insights into the Triassic evolution of marine ostracod diversity}




\subsection{Global diversity patterns}

During the Triassic, the global diversity of ostracods ranges from 11 genera in the Smithian (Early Triassic) to 82 in the Anisian and from five to 23 families in the Smithian and the Griesbachian respectively (Fig. 3A). The first peak of diversity in the Griesbachian (53 genera, 23 families) documents the decoupling of generic and familial diversity in the aftermath of the EPE as this Triassic maximum of familial diversity is not paralleled by that of genera, recorded later in the Anisian. A severe loss in diversity occurs in the Dienerian with 15 genera distributed into nine families. This pattern further develops in the Smithian that records the lowest diversity of the Triassic, at all taxonomic levels considered, with 11 genera and five families. These two patterns respectively illustrate the Griesbachian survival period, followed by a pauperisation of the assemblages that covers the entire Dienerian and Smithian, as discussed by Crasquin-Soleau et al. (2007) and Crasquin and Forel (2014). A progressive rediversification occurs in the Spathian (35 genera, 12 families) and further develops in the Anisian with a peak that reaches 83 genera, the maximum recorded for the Triassic interval. Here again, the familial and generic diversity are decoupled and may indicate that high taxonomic levels react more slowly than lower levels during periods of taxonomic restructuration. This observation further substantiates the previous reports of Crasquin-Soleau et al. (2007) and Crasquin and Forel (2014) in placing the first burst of the rediversification during the Spathian and its acme during the Anisian. The subsequent interval spanning from the Ladinian to the Rhaetian is for the first time characterized here in term of global ostracod diversity and records a seesawing diversity within a high-level plateau ranging from 60 (Norian) to 78 genera (Carnian), and from 17 (Ladinian, Norian) to 23 (Carnian) families.

These trends are underlain by varied patterns of extinction of survivors and emergence of newcomers that are for the first time described here (Fig. 3A). From the Griesbachian to the Smithian, only few new genera emerged, with a drop from 10 newcomers in the 
Griesbachian to three in the Smithian. The observed declining diversity for this interval therefore relates to rare radiations coupled with numerous extinctions in the Griesbachian, corresponding to the disappearance of Permian holdovers (24 genera). The subsequent low diversity maintained in the Dienerian and Smithian mainly reflects the stasis of newcomers and extinctions. On the opposite, the Spathian and Anisian rising diversity appears as the consequence of a burst of radiating genera, with a maximum in the Anisian (34). The entire Middle and Late Triassic interval is characterized by sustained extinctions, ranging from 19 genera during the Ladinian to 35 at the end of the Rhaetian, with the exception of the Norian during which only eight genera went extinct. This interval is also marked by the overall stable amount of radiating genera. This relative balance of extinctions and radiations resulted in the overall high plateau observed for this interval.

\subsection{Taxonomic features underlying diversity trends}

In terms of taxonomic structuration, the diversity loss from the Griesbachian to the Dienerian is related to three phenomena. The first is the final disappearance of seven of the eight Griesbachian palaeocopid families at the end of this stage (Aechminellidae, Buregiidae, Hollinellidae, Indivisiidae, Kloedenellidae, Knoxitidae, Paraparchitidae; Fig. 3B). No other family ends up in the Griesbachian (Fig. 2). The second feature relates to genera that are uniquely known in the Griesbachian and geographically restricted to China (Anxiania, Beichuania, Paramicrocheilinella) and Australia (Truncobairdia; Table 1). The third component is the last occurrence of numerous genera from diverse families as Bairdiidae (Orthobairdia), Bairdiodyprididae (Baschkirina, Silenites), Cavellinidae (Sulcella), Cytherissinellidae (Arqoviella), Healdiidae (Cytherellina), Pontocyprididae (Haworthina). Important Triassic taxa nevertheless root as early as in the Griesbachian: Hungarella (Healdiidae), Kerocythere (Cytheruridae), Mockella (Cytheruridae), Triassinella (Limnocytheridae). All these genera are restricted to the Triassic as none range up to the Jurassic. As for the families, only Limnocytheridae (Triassinella) radiated during this interval. 
The close analysis of the taxonomic structuration of Dienerian communities once again documents the decoupling of familial and generic trends as well as the very first roots of the rediversification. This stage is virtually neutral in terms of familial events, with only the disappearance of Amphissitidae. However, the generic rediversification is already visible with the emergence of 4 genera, Triassocythere (Bythocytheridae), Bektasia (Cavellinidae), Ptychobairdia (Bairdiidae), Lutkevichinella (Limnocytheridae).

The ostracod record shows no influence of this Smithian-Spathian event at the time of writing: this observation may relate to the fact that most of taxa at this time interval are benthic while this biotic event has affected nektonic organisms, as detailed earlier. An increased investigation of planktonic taxa during this interval, possibly in Romania and Hungary that already yielded promising observations (e.g., Forel and Grădinaru, 2018; Tóth and Cséfán, 2018), may provide new elements. The peculiarity of the Spathian diversification is that it is largely the result of genera returning to the fossil record after having been Lazarus through the EPE and/or the beginning of the Early Triassic. As a whole, they represent 19 of the 35 genera (54\%) recorded during the Spathian. Four genera re-enter the fossil record from the Late Permian: Spinocypris and Triassocypris (Paracyprididae), Paraberounella (Bythocytheridae) and Urobairdia (Bairdiidae). Those re-entering the fossil record from the Triassic are Kirkbyidae (Carinaknightina), Bairdiidae (Petasobairdia, Bairdiacypris, Ptychobairdia), Cytheruridae (Kerocythere), Healdiidae (Hungarella) and Cavellinidae (Bektasia), to cite only the most representative. This phenomenon is a less important contribution to the Anisian burst of diversity (17 of 82 genera, 21\%) and the Lazarus pattern is therefore of major importance to understand the dynamic of early recovery during the Triassic. The Spathian also documents the roots of the diversification of Cytheruridae and Limnocytheridae, both families further developing in the Anisian (Fig. 4; Table 1), as well as the maximal diversity of the Paracyprididae, that lasted until the Ladinian. This diversification further develops in the Anisian, which is of major importance in the macroevolution of ostracods during the Triassic as it records, for instance (Fig. 4): (1) the maximum of diversity of Bythocytheridae (18 genera including 13 newcomers) and of 
Cavellinidae (four genera including two newcomers), (2) the first Triassic occurrence of Beecherellidae following an important gap in their fossil record, (3) the on-set of the diversification of Cytherellidae and the true rediversification of Healdiidae, (4) the emergence and diversification of typically Triassic ornate Bairdiidae, which are further discussed later, (5) the first high point of the high diversity plateau for Cytheruridae, that will develop until the end of the Triassic in an overall increasing diversity trend. It records the highest radiation rate for this family, with three new genera (Blomella, Eucytherura, Gruendelicythere).

As part of the high-diversity plateau encompassing the Middle and Late Triassic, the Ladinian witnessed only few important biotic events for ostracods. The major event is the peak in diversity of Limnocytheridae (15 genera), that contrasts with all other families observed to date during this interval (Fig. 4). Most of the Ladinian Limnocytheridae were already present in the Anisian (e.g. Triassinella, Lutkevichinella, Renngartenella, Casachstanella, Simeonella) but three new genera emerged (Cytherissinella, Christellocythere, Reversiocythere). The Ladinian sees the emergence of the Mandelstaminidae (Rhombocythere) that will last, with this unique genus, until the Rhaetian.

The Carnian stage is a high-point of the Middle-Late Triassic diversity plateau that relates to the emergence of seven Bairdiidae genera, five ornate (Edithobairdia, Eisobairdia, Carinobairdia, Medwenitschia, Parurobairdia) and two smooth (Isobythocypris, Hiatobairdia). The re-entrance in the fossil record of Ceratobairdia and Parurobairdia is worth mentioning as it represents one of the longest Lazarus period known to date for ostracods during this interval (Changhsingian to Carnian). It also corresponds to the on-set of maximal diversity of Cytherellidae, with three genera (Cytherella, Issacharella, Leviella): this feature is maintained until the Rhaetian with the replacement of Issacharella by Cytherelloidea. Together with the Rhaetian, the Carnian constitutes the highest diversity for Cytheruridae (eight genera), of which only Metacytheropteron is new. A very peculiar aspect of the Carnian is the reemergence of Rectonariidae (three genera) that were Lazarus since their latest occurrence in the Changhsingian of South China (Yuan et al., 2009): the implications of this observation are discussed below. The Carnian sees the survivorship of a unique Cavellinidae (Bektasia), 
that will stay the last representative of this family until its disappearance at the end of the Rhaetian. It finally witnesses the roots of Protocytheridae (Klinglerella). Although several ostracod assemblages witness the degradation of environmental conditions related to the Carnian Humid Episode (e.g., Keim et al., 2001), the influence of this event on marine ostracod fauna still needs to be thoroughly studied. Typical Carnian taxa, such as Renngartenella sanctaecrusis or Simeonella brotzenorum Sohn, 1968, witness salinity issues related to the Carnian Pluvial event (e.g., Kristan-Tollmann and Hamenadi, 1973; Gerry et al., 1990; Monostori, 1994; Keim et al., 2001; Forel et al., in press), but these works only focus on the western tethyan zone and data are still lacking from eastern area (e.g., Forel et al., 2019b).

The Norian is also a period of great stability with no peculiar event in terms of ostracod biodiversity except the unique Triassic occurrence of Punciidae (Triassopuncia, Triassomanawa; Kozur, 1996). Prior to the end-Triassic extinction, the Rhaetian records the acme of several families, including Bairdiidae, Cytheruridae and Healdiidae. It also records the earliest known occurrences of major groups such as Progonocytheridae (Kinkelinella) and Cytheridae (Aparchitocythere, Parariscus). Finally, it yielded the latest known occurrence of Beecherellidae (Acantoscapha) and Rectonariidae (open nomenclature genera).

\section{Discussion}

\subsection{Triassic occurrences of Palaeozoic taxa}

\subsubsection{Palaeocopida}

Palaeocopida were major components of the Palaeozoic ostracod fauna and were widespread from shallow to deep marine waters (e.g., Jones, 1989; Becker and Wang, 1992; Casier and Lethiers, 1998; Olempska and Chauffe, 1999; Chitnarin et al., 2012). They were traditionally thought to have gone extinct at the EPE (e.g., Moore, 1961) but since the 80's, a 
growing body of literature documented their survival into the Early Triassic (Crasquin and Forel, 2014 and references therein). The persistence of living Palaeocopida has been evoked, Kirkbyoidea being considered by some as the forerunners of the Cretaceous to recent Punciidae (e.g., Schallreuter, 1968; Swanson, 1991). This question is still debated: some consider that there might be no living Palaeocopida and that Punciidae should rather be attributed to Cytherellidae (e.g., Whatley et al., 1993; Becker, 1997; Martens et al., 1998; Martin and Davis, 2001) while others recently revived the order Punciocopida Schallreuter, 1968 (Danielopol and Swanson, 2019). It is out of the scope of the present contribution to discuss this issue and the Punciidae documented from the Norian (Kozur, 1996) have been here attributed to the Punciocopida.

Eight Palaeocopida families survived in the Griesbachian (Fig. 2; Table 1) and in the direct aftermath of the EPE, they are part of all survival patches described earlier. When present, Paraparchitidae, Kirkbyidae, Kloedenellidae and Knoxitidae are only accessory components of the communities surviving in association with microbial deposits (e.g., Crasquin-Soleau and Kershaw, 2005; Forel, 2012, 2014; Forel et al., 2013a, b; Crasquin-Soleau et al., 2004a, b). Conversely, Hollinellidae (Hollinella) proliferate through the EPE in littoral clastic areas of South China (Forel et al., under review) and northern Vietnam (Crasquin et al., 2018). This phenomenon documents different adaptative abilities to peculiar environmental conditions to which these organisms were adapted. As such, Hollinella may radically differ from Bairdiidae in terms of adaptative abilities in being able to cope with high detrital influx.

Of the eight families occurring in the Griesbachian, only Kirkbyidae range higher in the Triassic (Fig. 2). They then disappear from the fossil record until their last known occurrence during the Carnian, Late Triassic (Forel et al., 2019a). An analysis of their generic diversity and environmental distribution in the Permian and Triassic reveals a unique pattern (Fig. 5). Over the studied interval, the Kirkbyidae's diversity reaches its acme in the Changhsingian with eight genera. Their diversity rapidly decreases through the EPE with redisual occurrences in the Griesbachian, Dienerian (Carinaknightina; Sohn, 1970) and Spathian (Carinaknightina; Crasquin-Soleau et al., 2006). They are for the last time reported from the 


\subsubsection{Deep-sea taxa}

The diversity of Triassic deep-sea ostracods, their taxonomic structuration, links to Permian taxa and palaeogeographical distribution are still poorly understood. In most cases, these ostracods have been secondarily silicified so that their occurrence in the fossil record requires sufficient amounts of available silica. The Permian and Triassic interval was marked by an interruption of the siliceous bioproduction, labelled "Early Triassic chert gap", related to the abrupt collapse of the thermohaline circulation (Beauchamp and Baud, 2002). It is assumed to have lasted until the late Spathian or Anisian (Kakuwa, 1996; Isozaki, 1997; Kozur, 1998a, b). Radiolarians that have been documented from the earliest Triassic of 
South China (Yang et al., 2012), Early Triassic of Japan (Sashida, 1991), Smithian-Spathian of New Zealand (Hori et al., 2003, 2011), Spathian of Japan (Kamata, 1999), early Spathian of Vietnam (Takahashi et al., 2017), to cite only a few, nevertheless demonstrate that siliceous productivity was maintained but may have been insufficient to allow the secondary silicification of ostracods during this interval. Most Palaeozoic deep-sea taxa reported from the Triassic, described and discussed below, may consequently have entered the Lazarus record through the EPE and its aftermath because of the low preservation potential of these poor faunas in a context of low dissolved silica.

Deep-sea ostracods from Triassic deposits have been increasingly documented since Kozur (1970) and the reader is referred to Crasquin and Forel (2014) for details and discussion on their Early and Middle Triassic distribution. Only recent discoveries of unquestionable and relatively diverse taxa in the Late Triassic, Carnian (Forel et al., 2019a) and Rhaetian (Forel and Grădinaru, under review) are here discussed. Typical Palaeozoic deep-sea taxa reported to date from the Triassic are Spinomicrocheilinella in the Anisian (Mette et al., 2014), Beecherellidae (Acanthoscapha) and Berounellidae from bathyal and abyssal environments of the entire Middle Triassic (Kozur, 1970, 1971, 1972; Crasquin-Soleau and Grădinaru, 1996; Sebe et al., 2013). These taxa have all been extended up to the Carnian and a new genus of Becherellidae (Gencella) implied that radiations were maintained, although at low rates (Forel et al., 2019a).

Rectonariidae are Palaeozoic deep-sea taxa in essence: they have been associated with deep-water masses in the Devonian-Carboniferous interval (e.g., Gründel, 1961; Olempska, 1981; Sanchez de Posada, 1987; Blumenstengel, 1992; Nazik et al., 2012) and they residually range to the uppermost Permian (Yuan et al., 2007). Until recently, they were considered as deep-sea victims of the EPE and have never been reported from previous analysis of Triassic deep-sea deposits. However, three genera, that are new to science but kept in open nomenclature because of the lack of material, unquestionably document their persistence in the Carnian (Forel et al., 2019a) and up to the Rhaetian (Forel and Grădinaru, 
under review). These observations first indicate that Rectonariidae survived the EPE and that they have been Lazarus taxa during the entire Early-Middle Triassic time interval.

Owing to the great sensitivity of deep-sea ostracods (e.g., Yasuhara et al., 2009), strong hypotheses are needed to explain the exceptional persistence of such residual Palaeozoic taxa through the EPE and up the the brink of the end-Triassic crisis. Two hypotheses are here considered. The first evokes a long-term yet unidentified refuge, which may have been located in the deep sea as these taxa were restricted to bathyal and abyssal zones through their fossil record and that they have never been observed from neritic deposits through the Permian and Triassic interval (Forel et al., 2019a). This refuge differs from those documented from neritic areas in the aftermath of the EPE by its much longer duration, from the Late Permian to the Rhaetian, and by its larger taxonomic composition. The second hypothesis implies the environmental stability of deep-sea areas around the Palaeo-Tethys and Neo-Tethys oceans where these assemblages have been described, through the EPE and more widely through the Triassic. This ostracod record has to be replaced within the discussion on the oceanic anoxia reported from the late Middle Permian to the early Middle Triassic, that may have occurred as several phases in the Early Triassic in northwestern Pangaea, South China, Japan, Turkey (late Changhsingian-early Dienerian, Smithian-early Spathian and middle Spathian; e.g., Isozaki, 1997; Grasby et al., 2012; Song et al., 2012; Lau et al., 2016; Wignall et al., 2016; Huang et al., 2017) and in the Middle Triassic in Japan and South China, including in deep-sea areas (Kubo et al., 1996; Sugitani and Mimura, 1998; Wignall et al., 2010; Huang et al., 2017; Song et al., 2012; Fujisaki et al., 2016; Soda and Onoue, 2018). This lengthy anoxia is considered as an important factor of the delayed recovery of marine biota after the EPE (e.g., Chen and Benton, 2012; Hallam, 1991). The present record of long-term survivorship of ostracods in the deep-sea is restricted to the Tethyan area as no such event is known from Panthalassa, possibly related to fundamental environmental differences between these oceanic realms. Long-term anoxia and ostracod persistence are only compatible in the deep-sea if pulses of anoxia themselves consisted of alternating anoxic and dysoxic intervals, or the refuge hypothesis should be favoured. 


\subsection{A focus on Bairdiidae: diversity and "phylogeny"}

Bairdiidae have been components of marine ecosystems from all time slices from the Ordovician (e.g., Truuver et al., 2012; Meidla, 1996) to present-days (e.g., Titterton and Whatley, 1988; Maddocks, 2013). Intense efforts have partly clarified the taxonomy of modern representatives of the "Bairdia dynasty" (Malz, 1988) with the establishment and/or revision of Neonesidea Maddocks, 1969, Paranesidea Maddocks, 1969, Bairdoppilata Coryell et al., 1935 and Triebelina van den Bold, 1946 (e.g., Maddocks, 1969; Maddocks, 2013, 2015). In the history of bairdiids, the Triassic is a unique interval with the explosive radiation of ornate taxa worldwide (e.g., Kollmann, 1960, 1963; Kristan-Tollmann, 1971a; Bolz, 1971a, b), most of which do not range into the Jurassic. The classification and phylogeny of Bairdiidae are major issues that the modern ostracodology needs to solve. Because of their importance in Triassic marine microfaunas, Bairdiidae are here treated separately and we discuss in detail the dynamics of their Triassic diversity and propose a "morphological phylogeny" of the ornate forms during the Permian and the Triassic.

\subsubsection{Triassic diversity}

Thirty-two Bairdiidae genera occur during the Triassic (Table 1). Bairdia, Acratia, Bythocypris have been termed "panchronic" taxa in Crasquin-Soleau et al. (2007). However, this notion of panchronism is problematic as it mistakenly implies the persistence of these taxa through the Phanerozoic and would, for instance for Bairdia, carry on and justify its abusive usage up to modern environments: we rather consider them as Palaeozoic-Early Mesozoic in essence. In terms of diversity dynamics, most patterns are similar to those described for the entire ostracod fauna during the Triassic (Fig. 3). Bairdiidae nevertheless significantly differ in that the Ladinian-Rhaetian interval rather witnesses a seesawing diversity within a general increase, resulting in their observed highest diversity in the Rhaetian (Fig. 6). Only few 


\subsubsection{Ornate bairdiids: elements of "morphological phylogeny"}

The classification of sculpted Bairdiidae is still subject to debates, mainly regarding the use of external sculptures as robust characters for generic scheme. Here, and until a complete phylogenetic analysis can be performed, we follow the original scheme of Kollmann (1960, 1963) as stated above. Any attempt to conceptualize the evolution of ornate bairdiids during the Triassic requires to be placed in perspective of the Permian record. Three groups are distinguished among Permian and Triassic ornate bairdiids, characterized by the temporal distribution and by the enhancement and growing complexity and sophistication of carapace ornamentation through time (Fig. 7): 
- Group 1: genera that originated prior or during the Permian and do not range into the Triassic. They are characterized by simple and not combined ornamentation structures: unique spine or knob (Xixionopsis, Spinobairdia, Sinabairdia), latero-ventral ridge (Vanganardia) or vertical lateral ridges (Arcibairdia). Only Abrobairdia displays a combination of ornate dorsal margin at left valve (ridge, nodes, spines) and ornamental structures (ridges, nodes) on the antero-central and postero-central area of each valve.

- Group 2: genera that radiated prior or during the Permian and range into the Triassic. Bairdiolites, Ceratobairdia, Mirabairdia and Parurobairdia went through the EPE as Lazarus taxa. They document an increasing complexity of the carapace ornamentation with more frequent combined structures as in Ceratobairdia, Mirabairdia and Ptychobairdia. This group also sees the strong development of ornament made of longitudinal and unstructured ridges as in Ceratobairdia and Ptychobairdia.

- Group 3: genera that originated during the Triassic. They display the highest sophistication of lateral combined ornaments. The pinnacle of this pattern is the fused ornament of Coronabairdia, that corresponds to the fusion of dorso-lateral and ventro-lateral ridges into a peripheral ring.

Owing to the temporal distribution of these groups, we propose the following scheme for the phylogeny of Triassic ornate Bairdiidae based on their ornament structures (Fig. 8). This scheme is rooted into the Kungurian and proposes that all subsequent ornate Bairdiidae derived from Petasobairdia. Petasobairdia Chen in Chen and Shi, 1982 ranges from the Sakmarian to the Rhaetian (Fig. 7) and is diagnosed by its ornate dorsal margin at left valve (ridge, nodes, horns) without combined lateral elements. During the Kungurian, Abrobairdia and Ceratobairdia may have derived from Petasobairdia: Abrobairdia by the development of dorso-lateral ridges and Ceratobairdia by the acquisition of latero-ventral structures. We propose that these two genera gave path to two distinct lineages: Ceratobairdia-lineage characterized by ridged ornaments and Abrobairdia-lineage with nodulose ornamentation. Abrobairdia ranges from the Kungurian to the Changhsingian, and is, as stated above, the earliest ornate bairdiid with combined ornamentation. Owing to this ornamental complexity 
compared to contemporaneous genera, Abrobairdia may have been the origin all subsequent genera with robust combined ornamentation. Abrobairdia seems closely related to Mirabairdia, which is the second oldest genera with combined ornament (oldest attested occurrence in the Changhsingian), therefore phylogenetically relating the groups 1 and 2 of our analysis. It is worth noting that Mirabairdia from the Capitanian of South China (M. sp. 1 in Zazzali et al., 2015) is re-attributed to Ceratobairdia because of its latero-ventral ridge. The earliest record of Mirabairdia may date back to the Wuchiapingian (M. sp. 2 in Zazzali et al., 2015) but the dorso-lateral features characteristic of this genus are not well expressed so that we consider that the earliest attested record of Mirabairdia is of Changhsingian age. The Abrobairdia-Mirabairdia evolutive unit sees the progressive restriction of dorsal ornamentation from several denticulations to 2 nodes or spines and the development of latero-ventral ornament structure in the Early Triassic. Subsequent genera with ornaments located at similar positions but of different morphologies, mainly Nodobairdia and Margarobairdia, may have derived from that Abrobairdia-Mirabairdia evolutive unit. The Ceratobairdia-lineage first saw the radiation of Vanganardia in the Capitanian, independently followed by the emergence of Parurobairdia. We consider that Ptychobairdia may have originated from Parurobairdia rather than from Vanganardia because Parurobairdia possesses both sub-ventral and dorsal/sud-dorsal structures contrary to Vanganardia that lacks dorsal elements. Rooting Ptychobairdia into Vanganardia, itself rooted into Ceratobairdia would imply the loss of dorsal structures from Ceratobairdia to Vanganardia and their subsequent re-development from Vanganardia to Ptychobairdia, we exclude this more complex scenario. In this hypothesis, Vanganardia and Parurobairdia Ptychobairdia constitute independent lineages that derived from Ceratobairdia. Vanganardia radiated in the Capitanian while the Parurobairdia-Ptychobairdia evolutive unit is rooted in the Changhsingian and diversified in the Spathian with the radiation of Ptychobairdia. It is worth noting that ventral structures of the Dienerian Ptychobairdia species shown in Crasquin-Soleau et al. (2006) are not clear so we exclude this record. Similarly, the 


\subsection{Rooting the Mesozoic Marine Revolution down to the Triassic}

The Mesozoic marine revolution changed the ecological structure of benthic communities and allowed for the rise of the Modern Fauna (Vermeij, 1977). During this major evolutionary episode, the development of durophagy and boring predation in marine predators triggered the colonization of infaunal habitats and the diversification of organisms with greater mobility and durophagous-resistant shells. This coevolution between marine predators and preys is traditionally considered to have taken place in the Jurassic and the Cretaceous (e.g., Roopnarine, 2006; Baumiller et al., 2010). However, the Triassic is increasingly regarded as the setting stage for the Mesozoic marine revolution as it marks the rise of the Modern Fauna and possibly of modern modes of predation (e.g., Tackett, 2016; Greene et al., 2011; Ros and Echevarría, 2011; Buatois et al., 2016; Klompmaker et al., 2016; Tackett and Tintori, 2019). Recent discoveries made on Late Triassic ostracods illustrate the important role ostracods have to play in this discussion.

\subsubsection{Triassic: the first step in the emergence of Modern ostracods}

As for other marine organisms, the Triassic is a period of major importance for the rise of typically Meso-Cenozoic, or Modern, ostracod fauna. To understand all mechanisms involved 
in this evolutive process, it is pivotal to clearly position the transition interval, which corresponds to the interval spanning from the emergence of the first typical representative of the Meso-Cenozoic forms, to the disappearance of the very last typical Palaeozoic taxa. Until recently, it was identifed from the Wuchiapingian to the Anisian for marine ostracods (Crasquin-Soleau et al., 2007; Crasquin and Forel, 2014). However, the observations described in the previous paragraphs imply that the upper limit of this transition interval is asynchronous for neritic and deep-sea taxa: in the Anisian for neritic taxa (Triassicindivisia; Forel and Crasquin, 2011a), in the Rhaetian for deep-sea ones (Rectonariidae; Forel and Grădinaru, under review). The position of the lower boundary of the transition interval for neritic ostracods is also moving with the description of new assemblages and understanding of the phylogeny of the typically Mesozoic ostracods and of their Permian roots. CrasquinSoleau et al. (2007) considered the first typical strongly shelled and ornamented Bairdiidae to occur in the Wuchiapingian (Sinabairdia: Becker and Wang, 1992; Fig. 7). Such ornate forms have nevertheless recently been documented down to the Capitanian (Zazzali et al., 2015; see above) and work currently in progress documents the occurrence of Petasobairdia and Ceratobairdia down to the Roadian of Texas, USA (work in progress). The Late Permian indeed appears as the acme of Petasobairdia as shown by the abundant records for this interval (e.g., Kozur, 1985; Shi and Chen, 1987; Crasquin-Soleau and Baud, 1998; Yi, 2004; Yuan et al., 2007; Crasquin et al., 2010; Forel, 2012). A recent report from the Sakmarian of Japan (Tanaka et al., 2018) roots this genus, as well as the origin of ornate Bairdiidae typical for the Triassic according to the phylegenetic scheme proposed here, down to the base of the Early Permian. We therefore consider that the lower boundary of the transition interval for neritic ostracods roots deep in the Early Permian. Conversely, the position of the lower boundary for deep-sea assemblages is more problematic as typical Jurassic deep-sea taxa and assemblages are virtually unrecognizable from their neritic counterparts as stated by Lord (1988). Lord and Lambourne (1991) documented a Pliensbachian, Early Jurassic, assemblage from Turkey related to a possible bathyal habitat owing to the dominance of Ptychobairdia and absence of Metacopina. More recently, an Early Jurassic assemblage 
indicative of the photic zone at water depth significantly shallower than calcite lysocline has been reported from Austria (Honigstein et al., 2014). The palaeobathymetry of this assemblage was inferred by its composition (dominance of bairdiid, near absence of cytheroids, lack of taxa that are important in coeval deposits such as Cladocopina, Healdiidae and Platycopina) rather than by the occurrence of taxa that unquestionably point to deep water zones. Inferring the emergence of typical deep-sea Mesozoic taxa possibly in the Triassic or before is therefore complex in the present state of our knowledge.

As detailed earlier in this work, the Triassic ostracod fauna is clearly distinct from the Palaeozoic one by the progressive disappearance of Palaeozoic components (e.g. Palaeocopida, deep-sea taxa) and the rise of taxa that will become typical of the Mesozoic and Modern marine assemblages. However, the massive diversification of ornate Bairdiidae is only known at this interval and also distinguishes it from the Mesozoic fauna. Conversely, the essentially Palaeozoic Metacopina (Healdiidae) diversified in the Triassic and the early to mid part of the Early Jurassic. They went extinct during the Early Toarcian Oceanic Anoxic Event (Boomer et al., 2008), which allowed for the Cytheroidea to further diversify until their dominance as seen in modern marine microfauna. The Triassic events therefore correspond to one step of this sequential on-set of the Mesozoic features of ostracod assemblages. The present analysis also documents the Triassic roots of Mesozoic families through several successive waves of radiation. Of them, Schulerideidae is an important component of Middle and Late Jurassic assemblages of Europe (e.g., Bate, 1977). Some have considered that it derived from the Pulviella-group [Speluncellini according to Kozur (1973a)], from the oldest representative of Praeschuleridea Bate, 1963 reported by Bate and Coleman (1975; Bate, 1977) or the Jurassic genus Ektyphocythere Bate, 1963 (Boomer et al., 2009). However, an undeniable Schulerideidae, attributed with doubt to Schuleridae, in the Carnian of South China documents the Late Triassic origins of this family (Forel et al., 2019b). The Carnian stage is also the period of radiation of Isobythocypris that later became widespread. To date, the oldest representatives of the Cardobairdia are from the Early Jurassic of England, Wales, Ireland and Australia (Ainsworth, 1986, 1987; Lord and Boomer, 1988; Boomer, 1991; Lord 
et al., 1993). Several species have nevertheless been recognized from the Rhaetian of the Black Sea and also root this genus down to the end of the Late Triassic (Forel and Grădinaru, under review).

As for important families, Cytheruridae are settled down in the Anisian with the roots of Eucytherura (Table 1; Fig. 4). An important discussion is needed here regarding Callicythere Wei, 1981 described from the Dienerian of South China (Wei, 1981). Originally attributed to Cytherissinellidae, Callicythere was later re-attributed to Bythocytheridae because of its midvalve sulcus and latero-ventral structures (Forel et al., 2013b). The inner structures and mainly muscular patterns of Callicythere have never been observed to date. However, considering the view of Whatley and Boomer (2000) that Bythocytheridae gave rise directly or indirectly to Cytheroidea during the Late Palaeozoic or Early Mesozoic interval and that one of the earliest cytheroid is Cytheruridae, we propose that the tethyan-wide Callicythere that occurs from the Capitanian to the Spathian with an acme in the Changhsingian may represent the link between Bythocytheridae and Cytheruridae.

\subsubsection{Ostracods: pivotal proxies to the Early Mesozoic-type food-webs}

Ostracods compose the diet of diverse organisms including bivalves, gastropods, echinoids, turtles, amphibians, fishes, annelids and other crustaceans (e.g., Lowndes, 1930; Harding, 1962; Reyment, 1966; Robertson, 1988; Penchaszadeh et al., 2004; Costa et al., 2006; Ghioca-Robrecht and Smith, 2008; Leal, 2008; Alcalde et al., 2010; Rossi et al., 2011; Vandekerkhove et al., 2012). Identifiable traces of predation on ostracods in the fossil record are related to drilling Naticidae and Muricidae gastropods (e.g., Maddocks, 1988; Reyment and Elewa, 2002), the oldest record being of Early Albian, Early Cretaceous, age (Maddocks, 1988). Predation on ostracods is most of the time disregarded and most works focus on relatively young assemblages (e.g., Reyment et al., 1987; Ruiz et al., 2010, 2011; VillegasMartin et al., 2019). Because of the small size of ostracods, they provide an important food source for juvenile gastropods as well as an alternative nutritive resource when regular preys 


\subsection{Geographical distribution} the dynamics of juvenile predators, for periods of prey impoverishment, or for the emergence of predation in the very first levels of marine trophic chains during the restructuration of benthic ecosystems associated with the on-set of the Mesozoic Marine Revolution. Until the end of the Cretaceous, drilling activity is erratic and it later increased in relation to the rise of Muricidae and Naticidae (e.g., Harper, 2006), the oldest group including being of Valanginian, Early Cretaceous age (Kaim, 2004). Occurrences of drill holes on macroinvertebrates are rare in the Triassic, but present in the Carnian and Norian (Klompmaker et al., 2016; Tackett and Tintori, 2019). Recently, the oldest evidence of drilling predation on ostracods, corresponding to an incomplete and rather non-functional hole, has been described on a left valve of a bairdiid (Forel et al., 2018). This observation also constitutes the first indication of drilling activity on micro-organisms in the Triassic. Although not functional, this pivotal evidence documents the onset of drilling abilities of juvenile predators, owing to the small dimensions of the trace (outer borehole diameter: $51.4 \mu \mathrm{m}$, outer borehole diameter: $18 \mu \mathrm{m})$. Furthermore, owing that Bairdiidae live above the sediment, the predator involved might have been hunting at the sediment surface (Forel et al., 2018). Rhaetian ostracods currently under description document the occurrence of two complete drill holes of smaller size than that of the Carnian sediments, that may indicate the increase of the efficiency of the drilling abilities of Triassic predators (Forel and Grădinaru, under review). Specialized durophagous predators during the Norian, mainly fishes, sharks and reptiles, have been considered as having an ecological influence on benthic communities (Tackett and Tintori, 2019). However, the ostracod successive records from the Carnian (Forel et al., 2018) and the Rhaetian (Forel and Grădinaru, under review) document the already advanced structuration of micro-predators in the Late Triassic, possibly corresponding to still unidentified gastropods as proposed by Klompmaker et al. (2016). 
The dynamic of marine ostracod provincialism during the Triassic is poorly known and has mainly been discussed in the 70's and 80's. Kozur (1973b) distinguished the southern boreal, tethyan and northern boreal provinces for Triassic conodonts and ostracods. KristanTollmann and Tollmann (1981, 1982) and Kristan-Tollmann (1986a, 1988a, b, 1991) proposed that the distribution of diverse fossil groups, including ostracods, was homogeneous within the Tethys during the Late Triassic. Forel and Moix (in press) recently dated the opening of communications between the Neo-tethys and Palaeo-tethys oceans of early Carnian rather than middle Carnian as generally suggested, and proposed that the previously described homogeneization of ostracod faunas during the Late Triassic may relate to this early event. However, the statement of Kristan-Tollmann (1988a) that the uniformity was already recognizable as early as end of the Anisian is problematic.

Here we provide insight into the provincialism of ostracod genera at each stage of the Triassic, following the first quantitative approach proposed by Forel and Grădinaru (2018) for the Anisian. For each time slice, localities that provided less than 3 genera are not considered as their paucity may bias the analysis, with an exception for Dienerian and Smithian that we tentatively characterize in spite of their extreme low diversity. Nekto-benthic taxa are excluded (Crasquin-Soleau and Grădinaru, 1996; Sebe et al., 2013; Forel and Grădinaru, 2018; Tóth \& Cséfán, 2018). For each stage we follow the method used by Forel and Grădinaru (2018) and produced a similarity symmetric matrix, following Q-mode analysis (Supplementary File 2; e.g., Henderson and Heron, 1976; Pielou, 1979; Janson and Vegelius, 1981; Digby and Kempton, 1987). Following Arias and Whatley (2009), we use the Jaccard's similarity coefficient (Jaccard, 1912) as it ranges from zero to one, emphasises presence instead of absence and is not influenced by differences in sample size (e.g., Cheetham and Hazel, 1969; Baroni-Urbani and Buser, 1976; Wolda, 1981; Magurran, 1988). We use the agglomerative clustering method 'unweighted pair group method with arithmetic mean' (UPGMA) which provides an unweighted arithmetic average between individuals (e.g., 


\section{Hazel, 1970; Anderberg, 1973; Podam, 1989; Shi, 1993). All analyses were done using the} statistical software package PAST (Hammer et al., 2001; Hammer and Harper, 2005). For some of the time slices, groupings of localities were made based on the palaeogeographical reconstructions of Scotese (2014). For each period of the Triassic, the classification of areas scrutinized in terms of similarities to their ostracod assemblages is shown in Fig. 9.

During the Griesbachian, the highest similarity is observed between palaeotethyan (Hungary, south China) and cimmerian (northern Iran, southern Turkey) localities, highlighting a core of peri-Palaeo-Tethyan biotas from which northern Italy and Slovenia are excluded in spite of their geographical closeness. Southern neotethyan communities from Himalaya (Tibet, India) show the highest similary to this peri-palaeotethyan group. Australian communities stand aside with the lowest degree of similarity, which may relate to distinct climatic regimes. Dienerian communities are extremely poor but they document similar patterns with Himalayan communities (Nepal, Pakistan) displaying more similarity with other the southern neotethyan localities (Tunisia) than with south Chinese ones. The Smithian communities are also very poor but document the exclusion of Tunisia and Russia that display no similarity with other tethyan communities. The Spathian burst of diversity sees the reinforcement of the similarity between peri-Palaeo-Tethyan biotas (Romania, Tibet, China), that record lower but still significant similarity with Israel on the southern margin of Neo-Tethys. Interestingly, these localities have no similarity with communities documented from Russia and Germany. This seems best explained by the emergence of brackish water Limnocytheridae in these areas (Triassinella, Lutkevichinella, Pulviella, Telocythere, Renngartenella, Speluncella). The isolation of russian and german communities further develops during the Anisian, as does the core of peri-Palaeo-Tethyan biotas (Hungary, Italy, Austria, Turkey, Romania) that documents the highest degree of similarity for this stage. Thailand, Israel and Jordan assemblages display a relatively high similarity corresponding to the possible emergence of a neo-tethyan region. Other regions (Himalaya, south China) show relatively low levels of similarity, that may be indicative of the dispersal of taxa related to the radiation stage. The Ladinian sees the individualization of two distinct clusters, the first one gathers France, 
Spain, Germany and Russia (with Scandinavia at a lesser level of similarity) and corresponds to areas of maximal diversification of brackish water Limnocytheridae. The second cluster corresponds to the enlargement of the peri-Palaeo-Tethyan region (Iran, Hungary, Balkan, Alps) to southern-neotethyan areas (Israel and Jordan). The close similarity of Canadian biota to this tethyan communities highlights the lack of data for this area during the Triassic and the possible existence of earlier trans-panthalassic faunal communications. The isolation of localities providing brackish water taxa further develops in the Carnian, as well as the establishement of a wide peri-tethyan region encompassing northern palaeo-tethyan and southern neo-tethyan areas. The high similarity of Canada with these tethyan localities further develops while Indonesia shows weaker levels of similarity, perhaps partly because of the lack of data. During the Norian, a relative uniformity of the biotas is observed within tethyan and panthalassic oceans, possibly illustrating the homogeneity of faunas and free migrations among oceans. Conversely, Germany and Slovenia stand aside with very low levels of similarity. The highest degree of similarity occurs between Germany, UK and Ireland, possibly illustrating a first type of biota of the Rhaetian Sea, which was a shallow epicontinental sea that covered the northwestern Europe during the latest Triassic (e.g., Fischer et al., 2012). Another type of Rhaetian Sea biota seems represented by the second level of similarity observed between France and Hungary. A third large cluster with lower similarities still documents the relative biotic uniformity within tethyan and panthalassic oceans (Japan, Australia, Romania, Austria, Iran, Iraq).

\subsubsection{Thoughts on the palaeogeography of radiations}

During most of the Triassic, South China appears as a key area for radiations. In the Griesbachian, the first occurrence of Limnocytheridae (Triassinella) in South China documents the emergence of this family on the eastern side of the Tethys very early in the Triassic. Conversely, the Griesbachian large distributions of Kerocythere and Hungarella seem to point to an incompleteness of their records: they are documented from South China 
and respectively from Italy and Hungary and India, and these large patterns indicate that they may have radiated earlier during the Late Permian. During the Carnian, South China saw the radiation of Schulerideidae, described higher, and Carinobairdia, a genus that was only known from the Norian-Rhaetian interval of Tyrol, Greece and Iran (Kollmann, 1963; Bolz, 1971a, b; Urlichs, 1972; Kristan-Tollmann, 1988; Kristan-Tollmann et al., 1991; Mette and Mohtat-Aghai, 1999; Hillebrandt et al., 2007; Urlichs and Krystyn, 2016; Mercier, 1966; Kristan-Tollmann et al., 1979, 1980). They migrated to the western Tethys later in the Late Triassic and diversified there. This pattern was coupled to a major palaeobathymetrical change, from their radiation on the deep-shelf followed by colonisation and ultimately distribution only in shallow waters (Forel et al., 2019b). These ostracod records are in line with growing evidence of the macroevolutionary importance of offshore origination in marine invertebrates (e.g., Lindner et al., 2008; Thuy, 2013; Bribiesca-Contreras et al., 2017; Hess and Thuy, 2018).

In essence, the Triassic history of Petasobairdia is tethyan but it may have been panthalassic in origin as shown by its earliest occurrence from a seamount of the Panthalassa (Japan) during the Early Permian, Sakmarian stage (Tanaka et al., 2018). It may have subsequently migrated to the Indochina Block, Thailand, as shown by its occurrence as early as the Artinskian, Early Permian, and late Roadian? (Chitnarin et al., 2012). A subsequent westerward expansion of the genus is illustrated by Capitanian, Middle Permian, occurrences in Russia (Gramm, 1997) and Turkey (Crasquin-Soleau et al., 2004b) It subsequently occurred in the Wuchiapingian of Greece (Crasquin-Soleau \& Baud 1998), Hungary (Kozur, 1985), Wuchiapingian and Changhsingian of China (Yuan et al., 2007; Shi and Chen, 1987; Crasquin et al., 2010; Yi, 2004; Forel, 2012; Li et al., 1989; Zazzali et al., 2015), Changhsingian of Iran (Forel et al., 2015) and Italy (Crasquin et al., 2008), documenting the colonization of the entire Palaeo-Tethys and Neo-Tethys appear as early as Wuchiapingian, Late Permian. These geographical features may show that Petasobairdia radiated in panthalassic waters during the Early Permian (Sakmarian) and that subsequently migrated westward to colonize palaeotethyan waters with the first step being Indochina Block in the 
Artinskian. During the Triassic, it is restricted to tethyan waters lato sensu and no record of this genus is known from Panthalassic deposits, possibly reflecting its palaeogeographical restriction. The large record of Petasobairdia during the Spathian (Tibet, Israel) following its last record restricted to China during the Griesbachian clearly indicates that dispersal continued during the post-EPE poverty phase (Dienerian-Smithian) although not recorded because of the lack of material. Middle and Late Triassic occurrences of this genus are still poorly documented on the eastern side of the tethyan area because of the lack of work carried on these areas, however its presence $a$ in the Anisian, Middle Triassic, of Thailand (Ketmuangmoon et al., 2018) shows the subsistence of this genus at least until the base of the Middle Triassic in this area.

Ceratobairdia and Parurobairdia have been Lazarus taxa during the entire Early and Middle Triassic and re-entered the fossil record during the Norian. Mirabairdia is Lazarus during the entire Early Triassic and re-entered the fossil record in the Anisian. The geographical distribution of this genus through time indicates that it radiated in South Chinese waters during the Changhsingian, Late Permian. When it re-entered the fossil record in the Anisian, it was already present along the entire northern margin of the Palaeotethys: dispersal may have occurred during the Early Triassic and the lazarus record of this genus may be related to preservation bias.

Ptychobairdia appeared to have radiated on the eastern side of tethyan area (South China; Crasquin-Soleau et al., 2006) where it was apparently confined during the entire early Triassic. Contrary to Petasobairdia, the records of Ptychobairdia do not indicate a westward migration until the Anisian, during which it colonized only the northern margin of the tethyan area (Hungary, Romania, Austria); a southern migration within the Tethys occurs from the Ladinian onwards. A final step of eastward migration took place in the Upper Late Triassic (Norian and Rhaetian) when it occurs in Panthalassic areas. This eastward movement might however have began earlier as shown by its large panthalassic distribution in Japan and Canada during the Norian. 


\section{Conclusions}

A database of all genera and families of marine and brackish ostracods gave us the opportunity to describe their diversity through the Triassic, a key period in the evolution of organisms in being bounded by two major biological crises and providing the earliest traces of the on-set of the Mesozoic marine revolution. We furthermore explored this database at the light of palaeoenvironmental, palaeocoecological and palaeogeographical contexts.

1. In terms of bulk diversity, the rediversification of ostracods following the EPE mainly occurred in a continuous burst spanning the Spathian and the Anisian. However, the taxonomic restructuration of ostracod communities began already in the Dienerian, during the poverty phase that followed the EPE. Although general diversity trends document the empoverished ostracod communities during most of the Early Triassic, the roots of their Triassic taxonomic rediversification are visible as early as the Dienerian. The entire Middle and Late Triassic document to a high-diversity plateau maintained by the equilibrium between extinctions and radiations.

2. The Triassic occurrences of Palaeozoic groups (Palaeocopida and deep-sea taxa) are reviewed and a restriction of the restriction of the environmental distribution of Kirkbyidae is reported in the Triassic. Deep-sea taxa, mainly Rectonariidae, residually range up the Rhaetian and point to the stability of environmental conditions through the EPE and the Triassic, in contrast with on-going discussion of long-term and widespread anoxia.

3. Ornate Bairdiidae radiated during two main phases, in the Anisian and in the Carnian. A "morphological phylogeny" proposes that all Permian and Triassic ornate Bairdiidae derived from Petasobairdia in the Kungurian. Two distinct lineages arose during the Permian: Ceratobairdia-lineage characterized by ridged ornaments and Abrobairdia-lineage with nodulose ornamentation.

4. The transition interval from the Palaeozoic to the Modern fauna appears as asynchronous for neritic and deep-sea taxa. It is here considered as spanning from the Early 
Permian to the Anisian for neritic ostracods. This interval is more complex to characterize for deep-sea taxa, in the absence of Jurassic taxa that may be facies-markers.

5. The importance of ostracods in exploring food-webs through time is highlighted. The recent discoveries of holes related to drilling predation of Carnian and Rhaetian ostracods are a unique opportunity to describe the very early stages of the structuration of typically Mesozoic predation type, in compartements of the trophic chains that are most of the time ignored. The characteristics of these holes on ostracods witness the increase of the efficiency of predators drilling abilities through the Triassic.

6. In terms of palaeogeographical distribution, peri-palaeo-tethyan and peri-neo-tethyan biotas appear as relatively distinct during most of the Early Triassic. The diversification burst saw the individualisation of a northern European biota characterized by the emergence of brackish water Limnocytheridae. A homogenization, possibly related to the dispersal of taxa after their radiation, became visible in the Anisian. This feature further developed in the Carnian with the establishement of a wide peri-tethyan region. In the Rhaetian, this feature is widespread and includes panthalassic localities, while at least two distinct biotas typical of the Rhaetian Sea may have bee, identified for the first time.

\section{Acknowledgements}




\section{References}

Agarwal, P.N., 1992. A record of Gombasekella Kozur from the Kalapani limestone formation, Kumaun Himalaya, Uttar Pradesh. Geoscience journal, 13(2), 181-183.

Ainsworth, N.R., 1986. Toarcian and Aalenian Ostracoda from the Fastnet Basin, offshore south-west Ireland. Bulletin of the Geological Survey of Ireland, 3, 277-336.

Ainsworth, N.R., 1987. Pliensbachian Ostracoda from the Fastnet Basin, offshore Southwest Ireland. Bulletin of the Geological Survey of Ireland, 4(1), 41-62.

Al-Khahab, S.A. and Al-Halawachi, J.M., 2018. Ostracoda Species from Upper Triassic of Baluti Formation (Amadiya Section) in Northern Iraq. Iraqi National Journal of Earth Sciences, 18(2), 61-68.

Alcalde, L., Derocco, N.N. and Rosset, S.D., 2010. Feeding in syntopy: Diet of Hydromedusa tectifera and Phrynops hilarii (Chelidae). Chelonian Conservation and Biology, 9, 33-44.

Alroy, J., Aberhan, M., Bottjer, D.J., Foote, M., Fürsich, F.T., et al., 2008. Phanerozoic Trends in the Global Diversity of Marine Invertebrates. Science, 321(5885), 97-100. Anderberg, M.R., 1973. Cluster analysis for applications. Academic Press, 359 pp.

Angiolini, L., Zanchi, A., Zanchetta, S., Nicora, A. and Vezzoli, G., 2013. The Cimmerian geopuzzle: new data from South Pamir. Terra Nova, 25, 352-360.

Arias, M.C. and Whatley, R.C., 2009. Multivariate hierarchical analyses of Early Jurassic Ostracoda assemblages. Lethaia, 42, 495-510.

Baresel, B., Bucher, H., Bagherpour, B., Brosse, M., Guodun, K. and Schaltegger, U., 2017. Timing of global regression and microbial bloom linked with the Permian-Triassic boundary mass extinction: implications for driving mechanisms. Scientific Reports, 7 , 43630.

Baroni-Urbani, C. and Buser, M.W., 1976. Similarity of binary data. Systematic Zoology, 25, $251-259$

Bate, R.H., 1963. Middle Jurassic Ostracoda from North Lincolnshire. Bulletin of the British Museum (Natural History), 8(4), 176-216. 
Bate, R.H., 1977. Jurassic Ostracoda of the Atlantic Basin. In: Swain, F.M. (ed.), Stratigraphic micropaleontology of Atlantic basin and borderlands. New York: Elsevier Scientific Pub. Co. Amsterdam, 231-244.

Bate, R.H. and Coleman, B.E., 1975. Upper Lias Ostracoda from Rutland and Hutingdonshire. Bulletin of the Geological Survey of Great Britain, 55, 1-42.

Baumiller, T.K., Salamon, M.A., Gorzelak, P., Mooi, R., Messing, C.G. and Gahn, F.J., 2010. Post-Paleozoic crinoid radiation in response to benthic predation preceded the Mesozoic marine revolution. Proceedings of the National Academy of Sciences, 107, 5893-5896.

Beauchamp, B. and Baud, A., 2002. Growth and demise of the Permian biogenic chert along northwest Pangea: evidence for the end-Permian collapse of the thermohaline circulation. Palaeogeography, Palaeoclimatology, Palaeoecology, 184, 37-63.

Becker, G., 1997. The Superfamily Kirkbyacea Ulrich \& Bassler, 1906. 3. Kirkbyidae \& Ulrich \& Bassler, 1906. Contributions to Palaeozoic Ostracod Classification [POC], No. 4. Neues Jahrbuch für Geologie und Paläontologie - Abhandlungen, 205(2), 159-175.

Becker, G., 2001. The Superfamily Bairdiacea Sars, 1888 - 1. Family Bairdiidae Sars, 1888 (Palaeozoic members only). Contributions to Palaeozoic Ostracod Classification [POC] 18. Neues Jahrbuch für Geologie und Paläontologie - Abhandlungen, 220(2), 267-294.

Becker, G. and Wang, S., 1992. Kirkbyacea and Bairdiacea (Ostracoda) from the Palaeozoic of China. Palaeontographica Abteilung A Palaeozoologie Stratigraphie, 224, 1-54.

Benton, M.J., 2016. The Triassic. Current Biology 26(23), R1214-R1218.

Benton, M.J., Zhang, Q.Y., Hu, S.X., Chen, Z.Q., Wen, W., Liu, J., Huang, J.Y., Zhou, C.Y., Xie, T., Tong, J.N., Choo, B., 2013. Exceptional vertebrate biotas from the Triassic of China, and the expansion of marine ecosystems after the Permo-Triassic mass extinction. Earth-Science Reviews, 125, 199-243.

Blumenstengel, H., 1992. Ostracodes from the Devonian-Carboniferous boundary beds in Thuringia (Germany). Annales de la Société Géologique de Belgique, 115, 483-489. 
van den Bold, W.A., 1946. Contribution to the study of Ostracoda, with special reference to the Tertiary and Cretaceous microfauna of the Caribbean region. Utrecht University thesis, Amsterdam, $167 \mathrm{pp}$.

Bolz, H., 1971a. Late Triassic Bairdiidae and Healdiidae. In: Oertli, H.J. (ed.), Paléoécologie des Ostracodes. Bulletin du Centre de Recherche, SNPA, 5 (Supplement), 717-745.

Bolz, H., 1971b. Die Zlambach-Schichten (alpine Obertrias) unter besonderer

Berucksichtigung der Ostrakoden, 1: Ostrakoden der Zlambach-Schichten, besonders Bairdiidae. Senckenbergiana lethaea, 52, 129-283.

Boomer, I., 1991. Lower Jurassic ostracod biozonation of the Mochras borehole. Journal of Micropalaeontology 9(2), 205-218.

Boomer, I. and Jellinek, T., 1996. On Ogmonconcha contractula Triebel. In: Boomer, I., Horne, D.J., Lord, A.R. and Siveter, D.J. (ed), A Stereo-Atlas of Ostracod Shells. British Micropalaeontological Society, London, 23, 53.

Boomer, I., Lord, A.R., and Crasquin, S., 2008. The extinction of Metacopida (Ostracoda). Senckenbergiana Lethaea, 88(1), 47-53.

Boomer, I., Lord, A.R., Page, K.N, Bown, P.R., Lowry, F.M.D. and Riding, J.B., 2009. The biostratigraphy of the Upper Pliensbachian-Toarcian (Lower Jurassic) sequence at IIminster, Somerset. Journal of Micropalaeontology, 28, 67-85.

Breda, A., Preto, N., Roghi, G., Furin, S., Meneguolo, R., Ragazzi, E., Fedele, P. and Gianolla, P., 2009. The Carnian pluvial event in the Tofane area (Cortina d'Ampezzo, Dolomites, Italy). Geol-Alp, 6, 80-115.

Bribiesca-Contreras, G., Verbruggen, H., Hugall, A.F. and O'Hata, T.D., 2017. The importance of offshore origination revealed through ophiuroid phylogenomics. Proceedings of the Royal Society, B 284, 20170160.

Brühwiler, T., Bucher, H., Brayard, A. and Goudemand, N., 2010. High-resolution biochronology and diversity dynamics of the Early Triassic ammonoid recovery: the Smithian faunas of the Northern Indian Margin. Palaeogeography, Palaeoclimatology, Palaeoecology, 297, 491-501. 
Brusatte, S.L., Nesbitt, S.J., Irmis, R.B., Butler, R.J., Benton, M.J. and Norell, M.A., 2010. The origin and early radiation of dinosaurs. Earth-Science Reviews, 101, 68-10.

Buatois, L.A., Carmona, N.B., Curran, H.A., Netto, R.G., Mángano, M.G. and Wetzel, A., 2016. The Mesozoic Marine Revolution. In: Mángano, M. and Buatois, L. (ed.), The Trace-Fossil Record of Major Evolutionary Events. Topics in Geobiology, 40. Springer, Dordrecht.

Bunza, G. and Kozur, H., 1971. Beiträge zur Ostracodenfauna der tethyalen Trias.

Geologisch-Paläontologische Mitteilungen Innsbruck, 1, 1-76.

Burgess, S.D., Bowring, S.A. and Shen, S.Z., 2014. High-precision timeline for Earth's most severe extinction. Proceedings of the National Academy of Sciences, 111(9), 33163321.

Campbell, I.H., Czamanske, G.K., Fedorenko, V.A., Hill, R.I. and Stepanov, V., 1992. Synchronism of the Siberian traps and the Permian-Triassic boundary. Science 258, 1760-1763.

Casier, J.G. and Lethiers, F., 1998. Les ostracodes survivants à l'extinction du Dévonien supérieur dans la coupe du Col de Devils Gate (Nevada, U.S.A.). Geobios, 30(6), 811821.

Cheetham, A.H. and Hazel, J.E. 1969. Binary (presence-absence) similarity coefficients. Journal of Paleontology, 43, 1130-1136.

Chen, Z.Q. and Benton, M.J., 2012. The timing and pattern of biotic recovery following the end-Permian mass extinction. Nature Geoscience, 5, 375-383.

Chen, D. and Shi, C., 1982. Latest Permian Ostracoda from Nantong, Jiangsu and from Miannyang, Hubei. Bulletin of Nanjing Institute of Geology and Palaeontology Academia Sinica, 4, 105-152.

Chitnarin, A., Crasquin, S., Charoentitirat, T., Tepnarong, P. and Thanee, N., 2012. Ostracods (Crustacea) of the Early-Middle Permian from Central Thailand (Indochina block). Part I. Order Palaeocopida. Geodiversitas, 34(4), 801-835. 
Cohen, K.M., Finney, S.C., Gibbard, P.L. and Fan, J.-X. (2013; updated). The ICS International Chronostratigraphic Chart. Episodes, 36, 199-204.

Coryell, H.N., Sample, C.H. and Jennings, P.H., 1935. Bairdoppilata, a new genus of Ostracoda, with two new species. American Museum Novitates, 777, 1-5.

Costa, P.F., Oliveira, R.F. and da Fonseca, L.C., 2006. Feeding ecology of Nereis diversicolor (O. F. Müller) (Annelida, Polychaeta) on estuarine and lagoon environments in the southwest coast of Portugal. Pan-American Journal of Aquatic Sciences, 1, 114126.

Crasquin, S. and Forel, M.-B. 2014. Ostracods (Crustacea) through Permian-Triassic events. Earth-Science Reviews, 137, 52-64.

Crasquin, S., Perri, M.C., Nicora, A. and de Wever, P., 2008. Ostracods across the PermianTriassic boundary in Western Tethys: the Bulla parastratotype (Southern Alps, Italy). Rivista Italiana di Palaeontologia e Stratigrafia, 114, 233-262.

Crasquin, S., Forel, M.-B., Feng, Q.L., Yuan, A.H., Baudin, F. and Collin, P.-Y., 2010. Ostracods (Crustacea) through Permian-Triassic boundary in South China: the Meishan stratotype (Zhejiang Province). Journal of Systematic Palaeontology, 8, 331-370.

Crasquin, S., Forel, M.-B., Yuan, A.H., Nestell, G. and Nestell, M., 2018. Species of Hollinella (Palaeocopida, Ostracoda, Crustacea) as stratigraphical indices of the Late PermianEarly Triassic post-extinction interval. Journal of Systematic Palaeontology, 16(3), 213224.

Crasquin-Soleau, S. and Grădinaru, E., 1996. Early Anisian ostracode fauna from the Tulcea unit (Cimmerian Notrh Dobrogean orogeny, Romania). Annales de Paléontologie, 82, $59-116$

Crasquin-Soleau, S. and Baud, A., 1998. New Permian ostracods of Greece (Hydra Island). Journal of Micropalaeontology, 17, 131-152.

Crasquin-Soleau, S., Marcoux, J., Angiolini, L. and Nicora, A., 2004a. Palaeocopida (Ostracoda) across the Permian-Triassic events: new data from South-Western Taurus (Turkey). Journal of Micropalaeontology, 23, 67-76. 
Crasquin-Soleau, S., Marcoux, J., Angiolini, L., Richoz, S., Nicora, A., Baud, A. and Bertho, Y., 2004b. A new ostracode fauna from the Permian-Triassic boundary in Turkey (Taurus, Antalya Nappes). Micropaleontology, 50(3), 281-296.

Crasquin-Soleau, S., Galfetti, T. and Bucher, H., 2006. Early Triassic ostracods from South China. Rivista Italiana di Paleontologia e Stratifrafia, 112(1), 55-75.

Crasquin-Soleau, S., Galfetti, T., Bucher, H., Kershaw, S. and Feng, Q.L., 2007. Ostracod fauna recovery in the aftermath of Permian-Triassic crisis: dating of the PalaeozoicMesozoic turnover. Hydrobiologia, 585, 13-27.

Dal Corso, J., Mietto, P., Newton, R.J., Pancost, R.D., Preto, N., Roghi, G. and Wignall, P.B., 2012. Discovery of a major negative ${ }^{13} \mathrm{C}$ spike in the Carnian (Late Triassic) linked to the eruption of Wrangellia flood basalts. Geology 40(1), 79-82.

Danielopol, D. and Swanson, K.M., 2019. Ostracod phylogeny and evolution - thirty years after "Manawan perspective". Geo-Eco-Marina, 25/2019, 219-251.

Davies, J.H., Marzoli, A., Bertrand, H., Youbi, N., Ernesto, M. and Schaltegger, U., 2017. End- Triassic mass extinction started by intrusive CAMP activity. Nature Communications, 8, 15596.

Dépêche, F. and Crasquin-Soleau, S., 1992. 26. Triassic marine ostracodes of the Australian margin (Holes 759B, 760B, 761C, 764A and 764B). Proceedings of the Ocean Drilling Program, Scientific Results, 122, 453-462.

Digby, P.G.N. and Kempton, R., 1987. Multivariate analysis of ecological communities. Chapman \& Hall, 206 pp.

Erwin, D.H., 1994. The Permo-Triassic extinction. Nature, 367(6460), 231-236.

Fischer, J., Voigt, S., Franz, M., Schneider, J.W., Joachimski, M.M., Tichomirowa, M., Götze, J. and Furrer, H., 2012. Palaeoenvironments of the late Triassic Rhaetian Sea: Implications from oxygen and strontium isotopes of hybodont shark teeth. Palaeogeography, Palaeoclimatology, Palaeoecology, 353, 60-72. 
Forel, M.-B., 2012. Ostracods (Crustacea) associated with microbialites across the PermianTriassic boundary in Dajiang (Guizhou Province, South China). European Journal of Taxonomy, 19, 1-34.

Forel, M.-B., 2014. Heterochronic growth of ostracods (Crustacea) from microbial deposits in the aftermath of the end-Permian extinction. Journal of Systematic Palaeontology, 13, 315-349.

Forel, M.-B., 2018. Ostracods (Crustacea), microbialites and their long shared history. Symposium of Amazing Geological Research for Sustainable Development: Case Study of Global Geopark Satun, Mineral Resources Research and Development Center, Department of Mineral Resources, Bangkok, Thailand.

Forel, M.-B. and Crasquin, S., 2011a. In the aftermath of the Permian-Triassic boundary mass extinction: ostracod new species and genus from South Tibet. Geodiversitas, 33, 247-263.

Forel, M.-B. and Crasquin, S., 2011b. Lower Triassic ostracods (Crustacea) from Meishan section, Permian - Triassic GSSP (Zhejiang Province, South China). Journal of Systematic Palaeontology, 9(3), 455-466.

Forel, M.-B. and Grădinaru, E., 2018. First report of Ostracods (Crustacea) associated with Bithynian (Anisian, Middle Triassic) Tubiphytes- microbial reef in the North Dobrogean Orogen (Romania). Papers in Palaeontology, 4(2), 211-244.

Forel, M.-B., Crasquin, S., Kershaw, S., Feng, Q.L. and Collin, P.-Y., 2009. Ostracods (Crustacea) and water oxygenation in earliest Triassic of South China: implications for oceanic events of the end- Permian mass extinction. Australian Journal of Earth Sciences, 56, 815-823.

Forel, M.-B., Crasquin, S., Brüwhiler, T., Goudemand, N., Bucher, H., Baud, A. and Randon, C., 2011. Ostracod recovery after Permian-Triassic boundary mass-extinction: The south Tibet record. Palaeogeography, Palaeoclimatology, Palaeoecology, 308, 160-170.

Forel, M.-B., Crasquin, S., Kershaw, S. and Collin, P.-Y., 2013a. In the aftermath of the endPermian extinction: the microbialite refuge. Terra Nova, 25, 137-143. 
Forel, M.-B., Crasquin, S., Hips, K., Kershaw, S., Collin, P.-Y. and Haas, J., 2013b.

Ostracods (Crustacea) from Permian-Triassic Boundary of Bálvány North section (Bükk Moun-tains, Hungary). Acta Palaeontologica Polonica, 58, 195-219.

Forel, M.-B., Crasquin, S., Chitnarin, A., Angiolini, L. and Gaetani, M., 2015. Precocious sexual di-morphism and Lilliput effect of Neo-Tethyan Ostracoda (Crustacea) through the Permian-Triassic boundary. Palaeontology, 58, 409-454.

Forel, M.-B., Ozsvárt P. and Moix, P., 2018. Carnian (Late Triassic) ostracods from the Sorgun Ophiolitic Mélange (Southern Turkey): Taxonomy, palaeoenvironment and evidence of predation. Palaeontologia Electronica, 21.2.26A, 1-23.

Forel, M.-B., Tekin, U.K., Okuyucu, C., Bedi, Y., Tuncer, A. and Crasquin, S., 2019a. Discovery of a long-term refuge for ostracods (Crustacea) after the end-Permian extinction: A unique Carnian (Late Triassic) fauna from the Mersin Mélange, southern Turkey. Journal of Systematic Palaeontology 17:9-58.

Forel, M.-B., Thuy, B. and Wisshak, M., 2019b. Digging into the ancestral stocks of Jurassic lineages: ostracods (Crustacea) from Carnian (Late Triassic) sponge mounds from the Maantang Formation (South China). Bulletin de la Société Géologique de France, 190(9), 1-29.

Forel, M.-B. and Moix, P., in press. Late Triassic ostracods from the Lycian Nappes, southwestern Turkey: implications on taxonomy and palaeobiogeographical distribution. Bulletin de la Société Géologique de France.

Forel, M.-B., Kolar-Jurkovšek, T. and Jurkovšek, B., in press. Ostracods from the «Raibl Beds» (Carnian, Late Triassic) of Belca section in Karavanke Mountains, northwestern Slovenia. Geodiversitas.

Forel, M.-B. and Grădinaru E., under review. Rhaetian (Late Triassic) ostracods from the offshore prolongation of North dobrogean Orogen into the Romanian Black Sea Shelf. Papers in Palaeontology.

Forel, M.-B., Bercovici, A. and Yu, J.X., under review. Ostracods after the end-Permian extinction in South China: insights into non-microbial survival. Micropaleontology. 
Fujisaki, W., Sawaki, Y., Yamamoto, S., Sato, T., Nishizawa, M., Windley, B. F. and Maruyama, S., 2016. Tracking the redox history and nitrogen cycle in the pelagic Panthalassic deep ocean in the Middle Triassic to Early Jurassic: Insights from redoxsensitive elements and nitrogen isotopes. Palaeogeography, Palaeoclimatology, Palaeoecology, 449, 397-420.

Galfetti, T., Hochuli, P.A., Brayard, A., Bucher, H., Weissert, H. and Vigran, J.O., 2007. Smithian/Spathian boundary event: evidence for global climatic change in the wake of the end-Permian biotic crisis. Geology, 35, 291-294.

Gerry, E., Honigstein, A., Rosenfeld, A., Hirsch, F. and Eshet, Y., 1990. The Carnian salinity crisis: ostracods and palynomorphs as indicators of palaeoenvironment. In: Whatley, R. and Maybury, C. (ed.), Ostracoda and global events. Chapman \& Hall, London, 87-99.

Ghioca-Robrecht, D.M. and Smith, L.M., 2008. Feeding ecology of polymorphic larval barred tiger salamanders in playas of the Southern Great Plains. Canadian Journal of Zoology, $86,554-563$.

Gliwa, J., Forel, M.-B., Crasquin, S., Ghaderi, A. and Korn, D., 2020. Ostracods from the end-Permian mass extinction in the Aras Valley section (Northwest Iran). Papers in Palaeontology, in press.

Goudemand, N., Romano, C., Leu, M., Bucher, H., Trotter, J.A. and Williams, I.S., 2019. Dynamic interplay between climate and marine biodiversity upheavals during the early Triassic Smithian-Spathian biotic crisis. Earth-Science Reviews, 195, 169-178.

Grasby, S.E., Beauchamp, B., Embry, A. and Sanei, H., 2012. Recurrent Early Triassic ocean anoxia. Geology, 41, 175-178.

Gramm, M.N., 1997. Ostracodes of the Chandalaz horizon (Upper Permian) of south Primorye. Mémoires de Géologie (Lausanne), 30, 61-66.

Greene, S.E., Bottjer, D.J., Hagdorn, H. and Zonneveld, J.-P., 2011. The Mesozoic return of Paleozoic faunal constituents: a decoupling of taxonomic and ecological dominance during the recovery from the end-Permian mass extinction. Palaeogeography, Palaeoclimatology, Palaeoecology, 308, 224-232. 
Gründel, J., 1961. Zur Biostratigraphie und Fazies der Gattendorfia - Stufe in

Mitteldeutschland unter besonderer Berücksichtigung der Ostracoden. Freiberger Forschungshefte C, 111, 53-173.

Gründel, J., 1978. Bemerkungen zur Phylogenie der Cytheracea Baird, 1850 s. str.

(Cytherocopina, Ostracoda). Zeitschrift für Geologische Wissenschaften, 6(5), 605-617.

Hallam, A., 1991. Why was there a delayed radiation after the end-Palaeozoic extinction? Historical Biology, 5, 257-262.

Hao, W., 1994. The development of the Late Permian-Early Triassic ostracod fauna in Guizhou Province. Geological Review, 40(1), 87-93.

Haq, B.U., 2018. Triassic Eustatic Variations Reexamined. GSA TODAY, 28(12), 4-9.

Hammer, Ø. and Harper, D.A.T., 2005. Paleontological data analysis. Blackwell, 351 pp.

Hammer, $\varnothing$. and Harper, D.A.T. and Ryan, P.D., 2001. PAST: Palaeontological Statistics software package for education and data analysis. Palaeontologia Electronica, 4, 9.

Harding, J.P., 1962. Mungava munda and four other new species of ostracod crustaceans from fish stomachs. The Natural History of Rennell Island, British Solomon Islands, 4, $51-62$

Harper, E.M., 2006. Dissecting post-Palaeozoic arms races. Palaeogeography, Palaeoclimatology, Palaeoecology, 232, 322-343.

Hautmann, M., Bagherpour, B., Brosse, M., Frisk, A., Hofmann, R., et al., 2015. Competition in slow motion: the unusual case of benthic marine communities in the wake of the endPermian mass extinction. Palaeontology, 58(5), 871-901.

Hazel, J.E., 1970. Binary coefficients and clustering in bio- stratigraphy. Geological Society of America Bulletin, 81, 3237-3252.

Henderson, R.A. and Heron, M.L., 1976. A probabilistic method of palaeobiogeographic analysis. Lethaia, 10, 1-15.

Hermann, E., et al., 2012. Climatic oscillations at the onset of the Mesozoic inferred from palynological records from the North Indian margin. Journal of the Geological Society, 169, 227-237. 
Hess, H. and Thuy, B., 2018. Emergence and early radiation of cyrtocrinids, with new species from a Lower to Middle Jurassic rock reef of Feuguerolles (Normandy, France). Swiss Journal of Palaeontology, 137, 133-158.

Hillebrandt, A.V., Krystyn, L. and Kürschner, W.M., 2007. A candidate GSSP for the base of the Jurassic in the Northern Calcareous Alps (Kuhjoch section, Karwendel Mountains, Tyrol, Austria). ISJS Newsletter, 34(1), 2-20.

Honigstein, A., Lord, A. and Thuy, B., 2014. Early Jurassic ostracods from the Glasenbach Gorge, Northern Calcareous Alps, Austria, and evidence for upper slope deposition. Neues Jahrbuch für Geologie und Paläontologie, Abhandlungen, 273, 1-11.

Hori, R.S., Campbell, J.D. and Grant-Mackie, J.A., 2003. Triassic Radiolaria from Kaka Point Structural Belt, Otago, New Zealand, Journal of the Royal Society of New Zealand, 33(1), 39-55.

Hori, R.S., Yamakita, S., Ikehara, M., Kodama, K., Aita, Y., Sakai, T., Takemura, A., Kamata, Y., Suzuki, N., Takahashi, S., Spörli, K.B. and Grant-Mackie, J.A., 2011. Early Triassic (Induan) Radiolaria and carbon-isotope ratios of a deep-sea sequence from Waiheke Island, North Island, New Zealand. Palaeoworld, 20, 166-178.

Horne, D.J., Cohen, A. and Martens, K., 2002. Taxonomy, morphology and biology of Quaternary and living Ostracoda. In: Holmes, J.A. and Chivas, A. (ed.), The Ostracoda: applications in Quaternary Research. Geophysical Monograph, American Geophysical Union, Washington, DC, 5-36.

Hornung, T. and Brandner, R., 2005. Biochronostratigraphy of the Reingraben Turnover (Hallstatt Facies Belt): local black shale events controlled by regional tectonics, climatic change and plate tectonics. Facies, 51(1-4), 460-479.

Hornung, T., Brandner, R., Krystyn, L., Joachimski, M.M., and Lorenz, K., 2007a.

Multistratigraphic Constraints on the NW Tethyan "Carnian Crisis". In: Lucas, S.G. and Spielmann, J.A. (ed.), The Global Triassic. New Mexico Museum of Natural History and Science Bulletin 41, 59-67. 
Hornung, T., Krystyn, L. and Brandner, R., 2007b. A Tethys-wide mid-Carnian (Upper Triassic) carbonate productivity crisis: evidence for the Alpine Reingraben Event from Spiti (Indian Himalaya)? Journal of Asian Earth Sciences, 30(2), 285-302.

Huang, Y., Chen, Z., Wignall, P. B., \& Zhao, L. (2017). Latest Permian to Middle Triassic redox condition variations in ramp settings, South China: Pyrite framboid evidence. Geological Society of America Bulletin, 129, 229-243.

Isozaki, Y., 1997. Permo-Triassic boundary superanoxia and stratified superocean: records from lost deep sea. Science, 276, 235-238.

Jaccard, P. ,1912. The distribution of flora in the alpine zone. The New Physiologist, 11, 3750.

Janson, S. and Vegelius, J., 1981. Measures of ecological association. Oecologia, 49, 371376.

Jones, P.J., 1989. Lower Carboniferous Ostracoda (Beytichicopida \& Kirkbyocopa) from the Bonaparte Basin, northwestern Australia. Bureau of Mineral Resources, Geology and Geophysics, Bulletin, 228, 1-97.

Kaim, A., 2004. The evolution of conch ontogeny in Mesozoic open sea gastropods. Acta Palaeontologica Polonica, 62:1-183.

Kakuwa, Y., 1996. Permian-Triassic mass extinction event recorded in bedded chert sequence in southwest Japan. Palaeogeography, Palaeoclimatology, Palaeoecology, $121,35-51$.

Kamata, Y. 1999. Lower Triassic (Spathian) radiolarians from the Kuzu area (Tochigi Prefecture, central Japan). Geodiversitas, 21(4), 657-673.

Kamoun, F., Peybernes, B., Montacer, M., Ben Youssef, M., Trigui, A. and Ghanmi, M., 1994. Application des concepts de la stratigraphie séquentielle aux séries triasiques du Sud de la Tunisie. Nouvelles données stratigraphiques et micropaléontologiques. Proceedings of the 4th Tunisian Petroleum Exploration Conference, 74, 213-235. 
Keim, L., Brandner, R., Krystyn, L. and Mette, W., 2001. Termination of carbonate slope progradation: an example from the Carnian of the Dolomites, Northern Italy. Sedimentary Geology, 143, 303-323.

Ketmuangmoon, P., Chitnarin, A., Forel, M.-B. and Tepnarong, P., 2018. Diversity and paleoenvironmental significance of Middle Triassic ostracods (Crustacea) from northern Thailand: Pha Kan Formation (Anisian, Lampang Group). Revue de micropaléontologie, 61, 3-22.

Klompmaker, A.A., Nützel, A., and Kaim, A., 2016. Drill hole convergence and a quantitative analysis of drill holes in mollusks and brachiopods from the Triassic of Italy and Poland. Palaeogeography, Palaeoclimatology, Palaeoecology, 457, 342-359.

Kolar-Jurkovšek, T., 1990. New ostracod and conodont species from the Triassic strata of Slovenia (NW Yugoslavia). Geologija, 31-32, 219-224.

Kollmann, K., 1960. Ostracoden aus der alpinen Trias. I Parabairdia n. g. und Ptychobairdia n. g. (Bairdiidae). Jahrbuch der Geologischen Bundesanstalt, 5, 79-105.

Kollmann, K., 1963. Ostracoden aus der alpinen Trias. II Weitere Bairdiidae. Jahrbuch der Geologischen Bundesanstalt, 106, 121-203.

Kornicker, L.S., Van Bakel, B.W.M., Fraaije, R.H.B. and Jagt, J.W.M., 2006. Revision of Mesozoic Myodocopina (Ostracoda) and a new genus and species, Mesoleberis hollandica, from the Upper Cretaceous of Belgium and The Netherlands. Zootaxa (1246), 15-54.

Kozur, H., 1970. Neue Ostracoden-Arten aus dem Obersten Anis des Bakonyhochlandes (Ungarn). Berichte des Naturwissenschaftlich-Medizinischen Vereins in Inns-bruck, 58, $384-428$.

Kozur, H., 1971. Die Bairdiacea der Trias. Teil 3: Einige neue Arten triassischer Bairdiacea und Bemerkungen zur Herkunft der Macrocyprididae (Cypridacea). Geologisch Paläontologische Mitteilungen Innsbruck, 1, 1-18. 
Kozur, H., 1972. Die Bedeutung triassischer Ostracoden für stratigraphische und paläoökologische Untersuchungen. Mitteilungen der Gesellschaft für Geologie und Bergbaustudien 21: 623-660.

Kozur, H., 1973a. Beiträge zur Stratigraphie und Paläontologie der Trias. GeologischPaläontologische Mitteilungen Innsbruck 3(1):1-30.

Kozur, H., 1973b. Faunenprovinzen in der Trias und ihre Bedeutung für die Klärung der Paläogeographie. Geologisch-Paläontologische Mitteilungen Innsbruck 3(8):1-41.

Kozur, H., 1985. Neue Ostracoden-Arten aus dem oberen Mittelkarbon (höheres Moskovian), mittel- und Oberperm des Bükk-Gebirges (N-Ungarn). Geologisch-Paläontologische Mitteilungen Innsbruck S2:1-145.

Kozur, H., 1996. Upper Triassic Punciacea, the connecting link between the Palaeozoic to Lower Triassic Kirkbyacea and the Cretaceous to Cenozoic Punciacea. Elf Aquitaine Production, Mémoire, 20, 257-269.

Kozur, H., 1998a. Some aspects of the Permian-Triassic boundary (PTB) and of the possible causes for the biotic crisis around the boundary. Palaeogeography, Palaeoclimatology, Palaeoecology, 143, 227-272.

Kozur, H., 1998b. Problems for evaluation of scenario of the Permian-Triassic boundary biotic crisis and of its cause. Geologia Croatica, 51, 135-162.

Kozur, H. and Bachmann, G.H., 2010. The Middle Carnian Wet Intermezzo of the Stuttgart Formation (Schilfsandstein), Germanic Basin. Palaeogeography, Palaeoclimatology, Palaeoecology, 290(1-4), 107-119.

Kozur, H., Aydin, M., Demir, O., Yakar, H., Göncüoglu, M.C. and Kuru, F., 2000. New Stratigraphic and Palaeogeographic Results from the Palaeozoic and Early Mesozoic of the Middle Pontides (Northern Turkey) in the Azdavay, Devrekani, Küre and Inebolu Areas: Implications for the Carboniferous-Early Cretaceous Geodynamic Evolution and Some Related Remarks to the Karakaya Oceanic Rift Basin. Geologia Croatica, 53, 209-268. 
Kristan-Tollmann, E., 1971. Weitere Beobachtungen an skulptierten Bairdiidae (Ostrac.) der alpinen Trias. Neues Jahrbuch für Geologie und Paläontologie Abhandlungen, 139, 5781.

Kristan-Tollmann, E., 1977a. On the development of the muscle-scar patterns in Triassic Ostracoda. In: Löffler, H. and Danielopol, D. (ed.), Proceedings of the Sixth International Symposium on Ostracoda (Saalfelden, Salzburg), 133-143.

Kristan-Tollmann, E., 1977b. Zur Evolution des SchlieBmuskelfeldes bei Healdiidae und Cytherellidae (Ostracoda). Neues Jahrbuch für Geologie und Paläontologie, 10, 621639.

Kristan-Tollmann, E., 1978. Bairdiidae (Ostracoda) aus den obertriadischen Cassianer Schichten der Ruones-Wiesen bei Corvara in Südtirol. Schriftenreihe der Erdwissenschaft-lichen Kommissionen, Österreichische Akademie der Wissenschaften, 4, 77-104.

Kristan-Tollmann, E., 1986a. Triassic of the Tethys and its relations with the Triassic of the Pacific realm. In: McKenzie, K.G. (ed.), Shallow Tethys 2. Proceedings of the International Symposium on Shallow Tethys 2, Wagga Wagga, 169-186.

Kristan-Tollmann, E., 1988a. Unexpected microfaunal communities within the Triassic Tethys. Geological Society of London, Special Publication, 37, 213-223.

Kristan-Tollmann, E., 1988b. A comparison of Late Triassic agglutinated foraminifera of Western and Eastern Tethys. Abhandlungen der Geologischen Bundesanstalt, 41, 245253.

Kristan-Tollmann, E., 1991. Triassic Tethyan microfauna in Dachstein Limestone blocks in Japan. In: Kotaka, T. et al. (ed.), Shallow Tethys 3. International Symposium on Shallow Tethys, Sendai, 1990, Sendai: Saito Ho-on Kai? Special Publication, 3, 169-186.

Kristan-Tollmann, E. and Hamedani, A., 1973. Eine spezifische MikrofaunenVergesellschaftung aus den Opponitzer Schichten des Oberkarn der niederösterreichischen Kalkvoralpen. Neues Jahrbuch für Geologie und Paläontologie Abhandlungen, 143(2), 193-222. 
Kristan-Tollmann, E. and Tollmann, A., 1981. Die Stellung der Tethys in der Trias und die Herkunft ihrer Fauna. Mitteilungen der Österreichischen Geologischen Gesellschaft, 74/75, 129-135.

Kristan-Tollmann, E. and Tollmann, A., 1982. Die Entwicklung der Tethystrias und Herkunft ihrer Fauna. Geologische Rundschau, 71(8), 987-101.

Kristan-Tollmann, E., Tollmann, A. and Hamedani, A., 1979. Beiträge zur Kenntnis der Trias von Persien. I. Revision der Triasgliederung. Rhätfazies in Raum von Isfaham und Kossener Fazieseinschlag bei Waliabad SE Abadeh. Mitteilungen der Österreichischen Geologischen Gesellschaft, 70, 119-190.

Kristan-Tollmann, E., Tollmann, A. and Hamedani, A., 1980. Beiträge zur Kenntnis der Trias von Persien. II. Zur Rhätfauna von Bagerabad bei Isfahan (Korallen, Ostracoden). Mitteilungen der Österreichischen Geologischen Gesellschaft, 73, 163-235.

Kristan-Tollmann, E., Lobitzer, H. and Solti, G., 1991. Mikropaläontologie und Geochemie der Kössener Schichten des Karbonatplatform-Becken-Komplexes Kammerköhralm Steinplatte (Tirol/Salzburg). In: Lobitzer, H. and Csaszar, G. (ed.), Jubiläumsschrift 20 Jahre Geologische Zusammenarbeit Österreich-Ungarn, Wien, Teil I. Geologische Bundesanstalt, Wien, 155-191.

Krystyn, L., 1978. Eine neue Zonengliederung im Alpin-Mediterranen Unterkar. In: Zapfe, H. (ed.), Beiträge zur Biostratigraphie der Tethys-Trias. Schriftenreihe der Erdwissenschaftlichen Kommission der Österreichischen Akademischen Wissenschaften, 4, 37-75.

Kubo, K., Isozaki, Y. and Matsuo, M., 1996. Color of bedded chert and redox condition of depositional environment: ${ }^{57} \mathrm{Fe}$ Mössbauer spectroscopic study on chemical state of iron in Triassic deep-sea pelagic chert. Journal of Geological Society of Japan, 102, 40-48 (in Japanese with English abstract).

Lau, K.V., Maher, K., Altiner, D., Kelley, B.M., Kump, L.R., Lehrmann, D.J. et al., 2016. Marine anoxia and delayed Earth system recovery after the end-Permian extinction. 
Proceedings of the National Academy of Sciences of the United States of America, 113, 2360-2365.

Leal, J.H., 2008. A remarkable new genus of carnivorous, sessile bivalves (Mollusca:

Anomalodesmata: Poromyidae) with descriptions of two new species. Zootaxa, 1764, 118.

Li, Z.S., Zhan, Z.P., Dai, J.Y., Jin, R.G., Zhu, X.F., Zhang, J.H., Huang, H.Q., Xu, D.Y., Yan, Z. and Li, H.M., 1989. Study on the Permian-Triassic Biostratigraphy and Event Stratigraphy of Northern Sichuan and Southern Shaanxi. Beijing: Geological Publishing House, pp. 435.

Lindner, A., Cairns, S.D. and Cunningham, C.W., 2008. From offshore to onshore: Multiple origins of shallow-water coral from deep-sea ancestors. PLoS ONE, 3(6), e2429.

Lord, A.R., 1972. The ostracod genera Ogmoconcha and Procytheridea in the Lower Jurassic. Bulletin of the Geological Society of Denmark, 21, 319-336.

Lord, A.R., 1982. Metacopine ostracods in the Lower Jurassic. In: Bannar, E.T. and Lord, A.R. (ed.), Aspects of Micropalaeontology. Allen \& Unwin, London, 262-277.

Lord, A.R., 1988. Ostracoda of the Early Jurassic Tethyan Ocean. In: Hanai, T., Ikeya, N and Ishizaki, K. (ed.), Evolutionary biology of ostracoda: Its fundamentals and applications. Proceedings of the Ninth International Symposium on Ostracoda, Shizuoka, Japan, 1985. Developments in Palaeontology and Stratigraphy 11, Kodansha, Tokyo and Elsevier, Amsterdam, 855-868.

Lord, A.R. and Boomer, I., 1988. The Lower and Middle Jurassic. In: Keen, M.C., Lord, A.R. and Whatley R.C. (ed.), British Micropalaeontological Society Field Guide, 6. The University College of Wales, Aberystwyth, 79, 1-22.

Lord, A.R. and Lambourne, D.C., 1991. Lower Jurassic ostracods from the Western Pontides, Turkey. Geologica Romana, 27, 381-387.

Lord, A.R., Malz, H. and Apthorpe, M., 1993. Lower Jurassic Ostracoda from off Western Australia. In: McKenzie, K.G. and Jones, P.J. (ed.), Ostracoda in the Earth and life 
sciences. Proceedings of the Eleventh International Symposium on Ostracoda. A.A. Balkema, Rotterdam, Brookfield, 724, 109-121.

Lowndes, A.G., 1930. Living ostracods in the rectum of a frog. Nature, 126, 958.

Maddocks, R.F., 1969. Revision of Recent Bairdiidae (Ostracoda). United States National Museum Bulletin 295, 126 pp.

Maddocks, R.F., 1988. One hundred million years of predation on ostracods: the fossil record in Texas. In: Hanai, T., Ikeya, N. and Ishizaki, K. (ed.), Evolutionary biology of ostracoda: Its fundamentals and applications. Proceedings of the Ninth International Symposium on Ostracoda, Shizuoka, Japan, 1985. Developments in Palaeontology and Stratigraphy 11, Kodansha, Tokyo and Elsevier, Amsterdam, 637-657.

Maddocks, R.F., 2013. New and poorly known species of Neonesidea (Bairdiidae, Ostracoda, Crustacea) from French Frigate Shoals, the Hawaiian Islands. Zootaxa, 3608(6), 457-510.

Maddocks, R.F., 2015. New and poorly known species of Bairdoppilata and Paranesidea (Bairdiidae, Ostracoda) from French Frigate Shoals and O'ahu, the Hawaiian Islands. Zootaxa, 4059(6), 277-317.

Maddocks, R.F. and Wouters, K., 1991. Triebelina? pustulata Keij, 1974 from the Maldive Islands more homeomorphy in the ornate Bairdiidae (Ostracoda). Bulletin de l'Institut Royal des Sciences naturelles de Belgique, Biologie, 60, 173-180.

Magurran, A.E., 1988. Ecological diversity and its measurement. Cambridge University Press, $413 \mathrm{pp}$.

Malz, H., 1988. The Bairdia Dynasty Review-Activities-Aspects. In: Hanai, T., Ikeya, N. and Ishizaki, K. (ed.), Evolutionary biology of ostracoda: Its fundamentals and applications. Proceedings of the Ninth International Symposium on Ostracoda, Shizuoka, Japan, 1985. Developments in Palaeontology and Stratigraphy 11, Kodansha, Tokyo and Elsevier, Amsterdam, 63-74.

Malz, H. and Lord, A.R., 1988. Recent Ornate Bairdiid Ostracoda: Origin and Distribution. In: Hanai, T., Ikeya, N. and Ishizaki, K. (ed.), Evolutionary biology of ostracoda: Its 
fundamentals and applications. Proceedings of the Ninth International Symposium on

Ostracoda, Shizuoka, Japan, 1985. Developments in Palaeontology and Stratigraphy 11, Kodansha, Tokyo and Elsevier, Amsterdam, 75-80.

Martens, K., Horne, D.J. and Griffiths, H.I., 1998. Age and diversity of non-marine ostracodes. In: Martens, K. (ed.), Sex and parthenogenesis: evolutionary ecology of reproductive modes in non-marine ostracods. Backhuys Publishers, Leiden, 37-55.

Martin, J.W. and Davis, G.E., 2001. An updated classification of the recent Crustacea. Natural History Museum of Los Angeles County, Contributions in Science, 39, 1-124.

Martindale, R.C., Foster, W.J. and Velledits, F., 2019. The survival, recovery, and diversification of metazoan reef ecosystems following the end-Permian mass extinction event. Palaeogeography, Palaeoclimatology, Palaeoecology, 513, 100-115.

Marzoli, A., Renne, P., Piccirillo, E., Bellieni, G. and De Min, A., 1999. Extensive 200-million year old continental flood basalts of the Central Atlantic magmatic province. Science, 284, 616-618.

McCoy, F., 1844. A synopsis of the characters of the Carboniferous limestone fossils of Ireland. Dublin University Press, Dublin, 207 pp.

McKenzie, K.G., 1982. Palaeozoic-Cenozoic Ostracoda of Tethys. Bollettino della Società Paleontologica Italiana, 21(2-3), 311-326.

Méhes, G., 1911. Über Trias-Ostrakoden aus dem Bakony. Resultate der wissenschaftlichen Erforschung des Balatonsees. Anhang zu Band 1, Teil 1, Paläontologie der Umgebung des Balatonsees, 3, 1-38.

Meidla, T., 1996. Late Ordovician Ostracodes of Estonia. Fossilia Baltica, 2, 222 pp.

Melnyk, D.H. and Maddocks, R.F., 1988. Ostracode biostratigraphy of the PermoCarboniferous of central and north-central Texas, Part I: paleoenvironmental framework. Micropaleontology, 34, 1-20.

Mercier, J.L., 1966. Etude géologique des zones internes des Hellénides en Macédoine centrale (Grèce). Thèse Paris et Ann. géol. Pays hellén., 1973, 20, 1-792. 
Mette, W., 2008. Upper Permian and lowermost Triassic stratigraphy, facies and ostracods in NW Iran - implications for the P/T extinction event. Stratigraphy, 5, 205-219.

Mette, W., 2010. Ostracods from the Upper Permian and Permian/Triassic boundary interval of Northwest Iran. Revista Espanola de Micropaleontologia, 42(1), 11-35.

Mette, W. and Mohtat-Aghai, P., 1999. Ostracods and foraminifera from Upper Trias-sic intrashelf basin deposits in the Northern Calcareous Alps. Geologisch Paläontologische Mitteilungen Innsbruck, 24, 45-77.

Mette, W., Honigstein, A. and Crasquin, S., 2014. Deep-water ostracods from the Mid-dle Anisian (Reifling Formation) of the Northern Calcareous Alps (Austria). Journal of Micropalaeontology, 34, 71-91.

Monostori, M., 1994. Ostracod evidence of the Carnian salinity crisis in the Balaton Highland, Hungary. Neues Jahrbuch für Geologie und Paläontologie, 193, 311-331.

Monostori, M. and Tóth, E., 2013. Ladinian (Middle Triassic) silicified ostracod faunas from the Balaton Highland (Hungary). Rivista Italiana di Paleontologia e Stratigrafia, 119, 303-323.

Moore, R.C., 1961. Treatise on Invertebrate Paleontology. Arthropoda 3, Crustacea, Ostracoda. Geological Society of America and University of Kansas Press, 442 pp.

Müller, G.W., 1894. Die Ostracoden des Golfes von Neapel und der angrenzenden Meeres Abschnilte. Fauna und Flora Neapel, 21, 1-404.

Nazik, A., Çapkinoglu, S. and Seker, E., 2012. Famennian ostracods from the Istanbul Zone (Gebze, Kocaeli, NW Turkey) and their paleogeographical relations. Geologica Carpathica, 63(5), 355-363.

Ogg, J.G., 2015. The mysterious Mid-Carnian "Wet Intermezzo" global event. Journal of Earth Sciences, 26(2), 181-191.

Olempska, E., 1981. Lower Carboniferous ostracodes of the Holy Cross Mountains, Poland. Acta Palaeontologica Polonica, 26, 35-57.

Olempska, E. and Chauffe, K., 1999. Ostracodes of the Maple Mill Shale Formation (Upper Devonian) of southeastern lowa, U.S.A. Micropalaeontology, 45(3), 304-318. 
Orchard, M.J., 2007. Conodont diversity and evolution through the latest Permian and early Triassic upheavals. Palaeogeography, Palaeoclimatology, Palaeoecology, 252, 93-117. Penchaszadeh, P.E., Bigatti, G. and Miloslavich, P., 2004. Feeding of Pseudechinus magellanicus (Philippi, 1857) (Echinoidea: Temnopleuridae) in the SW Atlantic Coast (Argentina). Ophelia, 58, 91-99.

Pielou, E.C., 1979. Biogeography. John Wiley \& Son, New-York, 351 pp.

Podam, J., 1989. New combinational clustering methods. Vegetatio, 81, 61-77.

Preto, N., Kustatscher, E. and Wignall, P.B., 2010. Triassic climates - state of the art and perspectives. Palaeogeography, Palaeoclimatology, Palaeoecology, 290(1-4), 1-10.

Raup, D.M., 1979. Size of the Permo-Triassic bottleneck and its evolutionary implications. Science, 206, 217-218.

Reichow, M.K., Pringle, M.S., Al'Mukhamedov, A.I., Allen, M.B., Andreichev, V.L., Buslov, M.M., Davies, C.E., Fedoseev, G.S., Fitton, J.G., Inger, S., Medvedev, A.Ya., Mitchell, C., Puchkov, V.N., Safonova, I.Yu., Scott, R.A. and Saunders, A.D., 2009. The timing and extent of the eruption of the Siberian Traps large igneous province: implications for the end-Permian environmental crisis. Earth and Planetary Science Letters, 277, 9-20.

Renne, P.R., Zhang, Z., Richards, M.A., Black, M.T. and Basu, A.R., 1995. Synchrony and causal relations between Permian-Triassic boundary crises and Siberian flood volcanism. Science, 269, 1413-1416.

Reyment, R.A., 1966. Preliminary observations on gastropod predation in the Western Niger Delta. Palaeogeography, Palaeoclimatology, Palaeoecology, 2, 81-102.

Reyment, R.A., 1967. Paleoethology and fossil drilling gastropods. Transactions of the Kansas Academy of Science, 70, 33-50.

Reyment, R.A. and Elewa, A.M.T., 2002. Predation by drills on Ostracoda. Predator - prey interactions in the fossil record. Topics in Geobiology, 20, 93-111.

Reyment, R.A., Reyment, E.R. and Honigstein, A., 1987. Predation by boring gastropods on Late Cretaceous and Early Palaeocene ostracods. Cretaceous Research, 8, 189-209. 
Rigo, M., Preto, N., Roghi, G., Tateo, F. and Mietto, P., 2007. A rise in the carbonate compensation depth of western Tethys in the Carnian (Late Triassic): deep-water evidence for the Carnian Pluvial Event. Palaeogeography, Palaeoclimatology, Palaeoecology, 246(2-4), 188-205.

Robertson, A.I., 1988. Abundance, diet and predators of juvenile banana prawns, Penaeus merguiensis, in a tropical mangrove estuary. Australian Journal of Marine and Freshwater Research, 39, 467-478.

Roghi, G., Gianolla, P., Minarelli, L., Pilati, C. and Preto, N., 2010. Palynological correlation of Carnian humid pulses throughout western Tethys. Palaeogeography, Palaeoclimatology, Palaeoecology, 290(1), 89-106.

Roopnarine, P.D., 2006. Extinction cascades and catastrophe in ancient food webs. Paleobiology, 32, 1-19.

Ros, S. and Echevarría, J., 2011. Bivalves and evolutionary resilience: old skills and new strategies to recover from the P/T and T/J extinction events. Historical Biology, 23, 411429.

Rossi, V., Benassi, G., Belletti, F. and Menozzi, P., 2011. Colonization, population dynamics, predatory behaviour and cannibalism in Heterocypris incongruens (Crustacea: Ostracoda). Journal of Limnology, 70, 102-108.

Ruiz, F., Abad, M., Gonzalez-Regalado, M.L., Civis, J., Gonzalez-Delgado, J.A., Mara García, E.X., and Toscano, A., 2010. Predation on Neogene ostracods of southwestern Spain. Rivista Italiana di Paleontologia e Stratigrafia, 116, 253-260.

Ruiz, F., Abad, M., Mara García, E.X., Toscano, A., Prudencio, M.I., Dias, M.I., and Galán, E., 2011. Predation on ostracod populations of two North African lagoons. Crustaceana, 84, 1537-1545.

Sanchez de Posada, L.C., 1987. Gruendelella, a new Carboniferous ostracod genus from the Namurian of the Cantabrian Mountains (N. Spain). Journal of Micropalaeontology, 6, 103-109. 
Sars, G.O., 1866. Oversigt af marine Ostracoder. Norske Videnskaps-Akademi, Förhandlingar, 1865, 1-130.

Sashida, K., 1991. Early Triassic Radiolarians from the Ogamata Formation, Kanto Mountains, Central Japan. Part 2. Transactions and Proceedings of the Palaeontological Society of Japan, New Series, 161, 681-696.

Saunders, A. and Reichow, M., 2009. The Siberian Traps and the end-Permian mass extinction: a critical review. Chinese Science Bulletin, 54, 20-37.

Schallreuter, R., 1968. Ordovizische Ostracoden mit geradem Schlossrand und konkaven Ventralrand. Wissenschaftliche Zeitschrift der Ernst-Moritz-Arndt-Universität Greifswald / Mathematisch-naturwissenschaftliche Reihe, 17, 127-152.

Schlager, W. and Schöelnberger, W., 1974. Das Prinzip stratigraphischer Wenden in der Schichtenfolge der Noedlichen Kalkalpen. Mitteilungen der Geologischen Gesellschaft Wien, 66(67), 165-193.

Schornikov, E.I., 1988. The Pathways of Morphological Evolution of Bythocytheridae In:

Hanai, T., Ikeya, N. and Ishizaki, K. (ed.), Evolutionary biology of ostracoda: Its fundamentals and applications. Proceedings of the Ninth International Symposium on Ostracoda, Shizuoka, Japan, 1985. Developments in Palaeontology and Stratigraphy 11, Kodansha, Tokyo and Elsevier, Amsterdam, 951-965.

Schornikov, E.I., 1990. Evolution and classification of Bythocytheridae. Courier Forschungsinstitut Senckenberg, 123, 291-302.

Scotese, C.R., 2014. Atlas of Middle \& Late Permian and Triassic Paleogeographic Maps, maps 43 - 48 from Volume 3 of the PALEOMAP Atlas for ArcGIS (Jurassic and Triassic) and maps 49 - 52 from Volume 4 of the PALEOMAP PaleoAtlas for ArcGIS (Late Paleozoic), Mollweide Projection, PALEOMAP Project, Evanston, IL.

Sebe, O., Crasquin, S. and Grădinaru, E., 2013. Early and Middle Anisian (Triassic) deepwater ostracods (Crustacea) from North Dobrogea (Romania). Revue de Paléobiologie, $32,509-529$. 
Sepkoski, J.J.Jr, 1984. A kinetic model of Phanerozoic taxonomic diversity. III. Post-

Paleozoic families and mass extinctions. Paleobiology, 10, 246-267.

Shi, G.R., 1993. Multivariate data analysis in palaecology and palaeobiogeography, a review. Palaeogeography, Palaeoclimatology, Palaeoecology, 105, 199-234.

Shi, C. and Chen, D., 1987. The Changhsingian ostracodes from Meishan Changxing, Zhejiang. Stratigraphy and palaeontology of systemic boundaries in China. Permian and Triassic Boundary, 5, 23-80.

Simms, M.J. and Ruffell, A.H., 1989. Synchroneity of climatic change and extinctions in the Late Triassic. Geology, 17, 265-268.

Simms, M.J. and Ruffell, A.H., 1990. Climatic and biotic change in the late Triassic. Journal of the Geological Society, 147(2), 321-327.

Soda, K. and Onoue, T., 2018. Paleoenvironmental reconstruction for termination stage of Superanoxia in Middle Triassic (Anisian) sedimentary sequence of the Mino belt, central Japan. Island Arc, 27(6), [e12262].

Sohn, I.G., 1960. Paleozoic species of Bairdia and related genera. United States Geological Survey Professional Paper, 330-A, 1-105.

Sohn, I.G., 1968. Triassic ostracodes from Makhtesh Ramon, Israel. Bulletin of the Geological Survey of Israel, 44, 1-71.

Sohn, I.G., 1970. Early Triassic Marine Ostracodes from the Salt Range and Surghar Range, West Pakistan. In: Kummel, B. and Teichert, C. (ed.), Stratigraphic Boundary Problems: Permian and Triassic of West Pakistan. Special publication. Department of Geology, University of Kansas, Lawrence, 149-206.

Song, H., Wignall, P.B., Tong, J., Bond, D.P.G., Song, H., Lai, X. and Chen, Y., 2012. Geochemical evidence from bio-apatite for multiple oceanic anoxic events during Permian-Triassic transition and the link with end-Permian extinction and recovery. Earth and Planetary Science Letters, 353, 12-21. 
Stanley, S.M., 2009. Evidence from ammonoids and conodonts for multiple early Triassic mass extinctions. Proceedings of the National Academy of Sciences of the United States of America, 106, 15264-15267.

Stanley, S.M., 2016. Magnitudes of major marine mass extinctions. Proceedings of the National Academy of Sciences of the United States of America, 113(42), 6325-6334.

Stephenson, M.B., 1946. Glyptobairdia, a new genus of Ostracoda. Journal of Paleontology, $20,345-347$.

Sugitani, K. and Mimura, K., 1998. Redox change in sedimentary environments of Triassic bedded cherts, central Japan: Possible reflection of sea-level change. Geological Magazine, 135, 735-753.

Sun, Y.D., Joachimski, M.M., Wignall, P.B., Yan, C.B. Chen, Y.L., Jiang, H.S., Wang, L.D. Lai, X.L., 2012. Lethally hot temperatures during the early Triassic greenhouse. Science, 338(6105), 366-370.

Swanson, K.M., 1991. Distribution, affinities and origin of the Punciidae (Crustacea, Ostracoda). Memoirs of the Queensland Museum, 31, 77-92.

Tackett, L.S., 2016. Late Triassic durophagy and the origin of the Mesozoic marine revolution. PALAIOS, 31, 122-124.

Tackett, L.S. and Tintori, A., 2019. Low drilling frequency in Norian benthic assemblages from the southern Italian Alps and the role of specialized durophages during the Late Triassic. Palaeogeography, Palaeoclimatology, Palaeoecology, 513, 25-34.

Takahashi, O., Maekawa, T., Komatsu, T., Phong Nguyen, Duc, Tien Dinh, Cong and Hung Doan, Dinh, 2017. Early Spathian (Late Olenekian, Early Triassic) Radiolaria from the Bac Thuy Formation, northeastern Vietnam. Revue de Micropaléontologie, 60(1), 171178.

Tanaka, G., Miyake, Y., Ono, T., Yuan, A.H., Ichida, M., Maeda, H. and Crasquin, S., 2018. Early Permian (Cisuralian) ostracods from Japan: characteristic ostracod assemblage from a seamount of the Panthalassic Ocean. Zootaxa, 4515, 1-67. 
Thuy, B., 2013. Temporary expansion to shelf depths rather than an onshore-offshore trend:

The shallow-water rise and demise of the modern deep-sea brittle star family

Ophiacanthidae (Echinodermata: Ophiuroidea). European Journal of Taxonomy, 48, 1242.

Titterton, R. and Whatley, R., 1988. Recent Bairdiinae (Crustacea, Ostracoda) from the Solomon Islands. Journal of micropalaeontology, 7(2), 111-142.

Tóth, E. and Cséfán, T., 2018. Rare myodocopid ostracods from Mesozoic sections of Hungary: summary, revision and description of new taxa. Zootaxa, 4374(3), 350-374.

Triebel, E., 1941. Zur Morphologie und Ökologie der fossilen Ostracoden mit Beschreibung einiger neuer Gattungen und Arten. Senckenbergiana, 23, 294-400.

Truuver, K., Meidla, T., Ainsaar, L., Bergström, J. and Tinn, O., 2012. Stratigraphy of the Ordovician-Silurian boundary interval in Östergötland, Sweden, based on ostracod distribution and stable carbon isotopic data. GFF, 134(4), 295-308.

Urlichs, M., 1972. Ostracoden aus den Kössener Schichten und ihre Abhängigkeit von der Ökologie. Mitteilungen der Gesellschaft der Geologie und Bergbaustudenten in Österreich, 21, 661-710.

Urlichs, M. and Krystyn, L., 2016. Stratigraphic Significance of the early Rhaetian ostracods From The proposed Norian/Rhaetian GSSP At Steinbergkogel (late Triassic, Upper Austria). Albertiana, 43, 19-23.

Vandekerhove, J., Namiotko, T., Hallmann, E. and Martens, K., 2012. Predation by macroinvertebrates on Heterocypris incongruens (Ostracoda) in temporary ponds: impacts and responses. Fundamental and Applied Limnology, 181, 39-47.

Vermeij GJ (1977) The Mesozoic marine revolution: Evidence from snails, predators and grazers. Paleobiology 3:245-258.

Villegas-Martin, J., Ceolin, D., Fauth, G. and Klompmaker, A.A., 2019. A small yet occasional meal: predatory drill holes in Paleocene ostracods from Argentina and methods to infer predation intensity. Palaeontology, 62(5), 731-756. 
Wang, S., 1978. Late Permian and Early Triassic ostracods of Western Guizhou and Northeastern Yunnan. Acta Palaeontologica Sinica, 17(3), 277-308.

Wei, M., 1981. Early and Middle Triassic Ostracods from Sichuan. Acta Palaeontologica Sinica, 20(6), 501-510.

Wei, M, Li, Y.W., Jiang, Z.W. and Xie, L.C., 1983. Subclass Ostracoda. In: Chengdu Institute of Geology and Mineral Resources (ed.), Palaeontological Atlas of Southwest China, Guizhou. Volume of Microfossils. Beijing, China: Geological Publishing House, 23-254 (in Chinese).

Whatley, R.C. and Moguilevsky, A., 1998. The origins and early evolution of the Limnocytheridae (Crustacea, Ostracoda). What about Ostracoda! Actes du 3e Congrès Européen des Ostracodologistes, 1996. Bulletin des centres de recherches explorationproduction Elf-Aquitaine, Mémoire, 20, Pau, France, 271-285.

Whatley, R.C. and Boomer, I., 2000. Systematic review and evolution of the early Cytheruridae (Ostracoda). Journal of Micropalaeontology, 19, 139-151.

Whatley, R.C., Siveter, D.J. and Boomer, I., 1993. Athropoda Crustacea (Ostracoda). In: Benton, M.J. (ed.), The fossil record 2, Chapman and Hall, London, 343-256.

Wignall, P.B., Bond, D.P.G., Kuwahara, K., Kakuwa, Y., Newton, R. J. and Poulton, S.W., 2010. An 80 million year oceanic redox history from Permian to Jurassic pelagic sediments of the Mino-Tamba terrane, SW Japan, and the origin of four mass extinctions. Global and Planetary Change, 71, 109-123.

Wignall, P.B., Bond, D.P.G., Sun, Y.D., Grasby, S.E., Beauchamp, B., Joachimski, M.M. and Blomeier, D.P.G., 2016. Ultra-shallow-marine anoxia in an Early Triassic shallow-marine clastic ramp (Spitsbergen) and the suppression of benthic radiation. Geological Magazine, 153, 316-331.

Wolda, H., 1981. Similarity indices, sample size and diversity. Oecologia, 50, 296-302.

Yang, B., Lai, X., Wignall, P.B., Jiang, H., Yan, C., and Sun, Y.D, 2012. A newly discovered earliest Triassic chert at Gaimao section, Guizhou, southwestern China.

Palaeogeography, Palaeoclimatology, Palaeoecology, 344-345, 69-77. 
Yasuhara, M., Okahashi, H. and Cronin, T.M., 2009. Taxonomy of Quaternary Deep-Sea Ostracods from the Western North Atlantic Ocean. Palaeontology, 52, 879-931.

Yi, W., 1992. Ostracoda Fauna of the Late Permian and Early Triassic in Dongkeng Area of Datian County, Fujian Province. Acta Palaeontologica Sinica, 11, 103-114. [In Chinese with English abstract].

Yi, W., 2004. Ostracodes from the Upper Permian and Lower Triassic at the Kongtongshan section of Datian, Fujian. Acta Palaeontologica Sinica, 43, 556-570.

Yuan, A.H., Crasquin-Soleau, S., Feng, Q.L. and Gu, S., 2007. Latest Permian deep-water ostracods from Southwestern Guangxi, South China. Journal of Micropalaeontology, 26, 169-191.

Yuan, A.H., Crasquin-Soleau, S., Feng, Q.L. and Gu, S., 2009. Ostracods from uppermost Permian siliceous and muddy rocks of Guizhou, Guangxi and Anhui. Acta Micropalaeontologica Sinica, 26, 385-403.

Zazzali, S., Crasquin, S., Deconinck, J.-F. and Feng, Q.L., 2015. Biodiversity across the Guadalupian-Lopingian Boundary: first results on the ostracod (Crustacea) fauna, Chaotian section (Sichuan Province, South China). Geodiversitas, 37(3), 283-313. 


\section{Figure captions}

Figure 1. A, End-Permian and Triassic timescale with absolute ages from Cohen et al. (2013, updated version 2020) and recovery pattern of ostracods after the end-Permian extinction, modified from Crasquin and Forel (2014). B, palaeogeographical map of the Anisian, Middle Triassic, modified from Angiolini et al. (2013).

Figure 2. Stratigraphical distribution of ostracod families during the Triassic. Arrows indicate older ranges (directed downward) and younger ranges (directed upward).

Figure 3. A, Total generic diversity of ostracods given for each time slice of the Triassic (black curve). For each interval, the number of newly originated genera (orange) and genera going extinct at the end of each stage (blue) are shown as histograms. B, Proportion of families per orders for each time slice of the Triassic.

Figure 4. Total generic diversity of Cytheruridae, Limnocytheridae, Bythocytheridae, Cavellinidae, Cytherellidae given for each time slice of the Triassic (black line). For each interval, the number of newly originated genera is given in dashed line.

Figure 5. Total generic diversity and palaeoenvironmental distribution of Kirkbyidae for each time slice of the Permian and Triassic. \$

Figure 6. Total generic diversity of Bairdiidae given for each time slice of the Triassic (black line). For each interval, the number of newly originated genera (orange) and genera going extinct at the end of each stage (blue) are shown as histograms.

Figure 7. Stratigraphical distribution of ornate Bairdiidae for each time slice of the Permian and Triassic. 
Figure 9. Dendrograms of UPGMA analysis based on diverse loci for each stage of the Triassic. B., S., S. (Ladinian) stands for Bosnia, Slovenia and Slovakia; S., Yu. (Carnian) stands for Slovenia and Yugoslavia.

Table 1. Stratigraphical distribution of ostracod genera during the Triassic. Blue boxes indicate observed occurrences; grey boxes indicate inferred occurrences.

Supplementary File 1. Complete list of references used to create the database of Triassic ostracod genera and families.

Supplementary File 2. Matrices of ostracod genera distribution during each stage of the Triassic. 


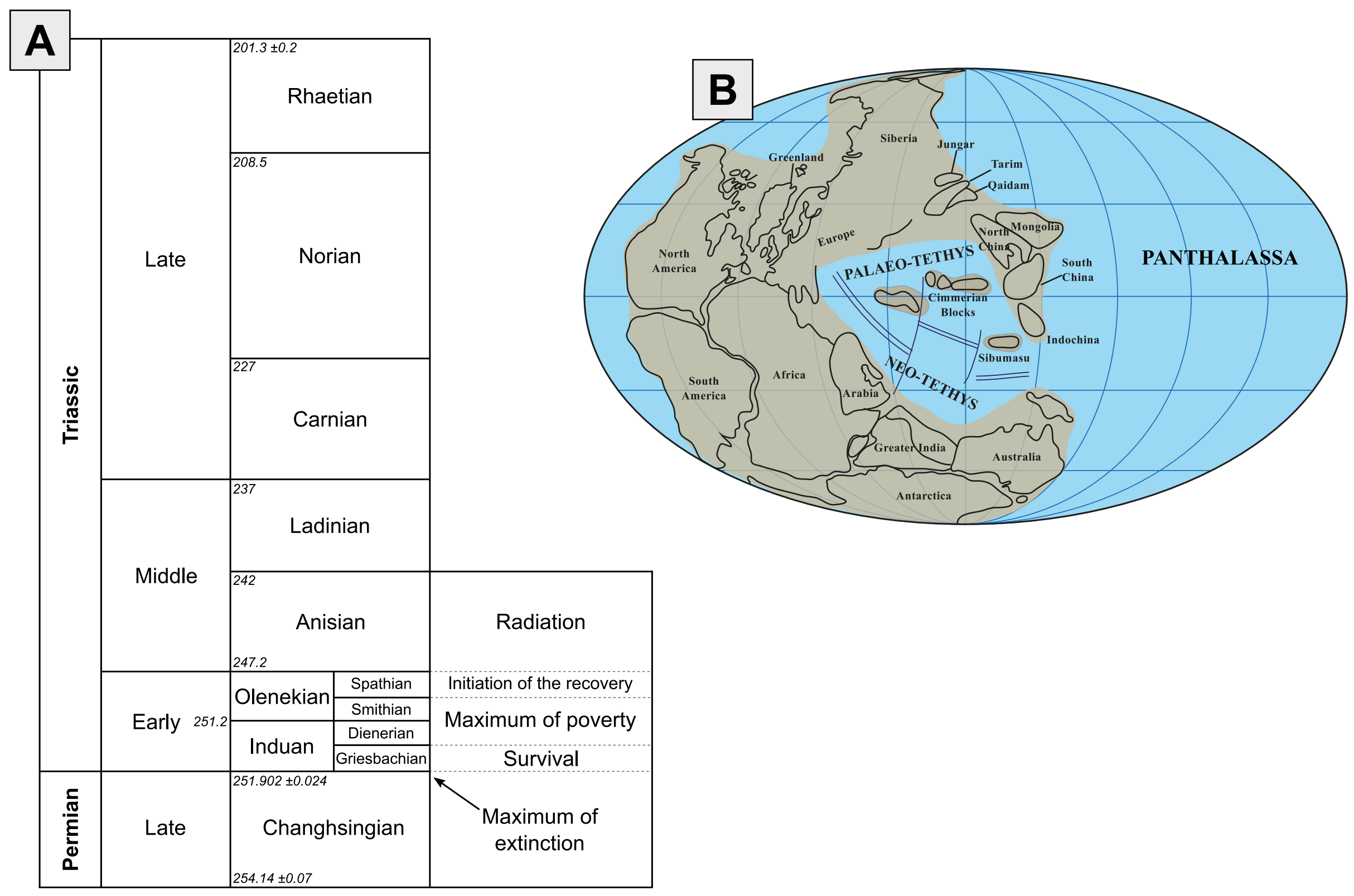




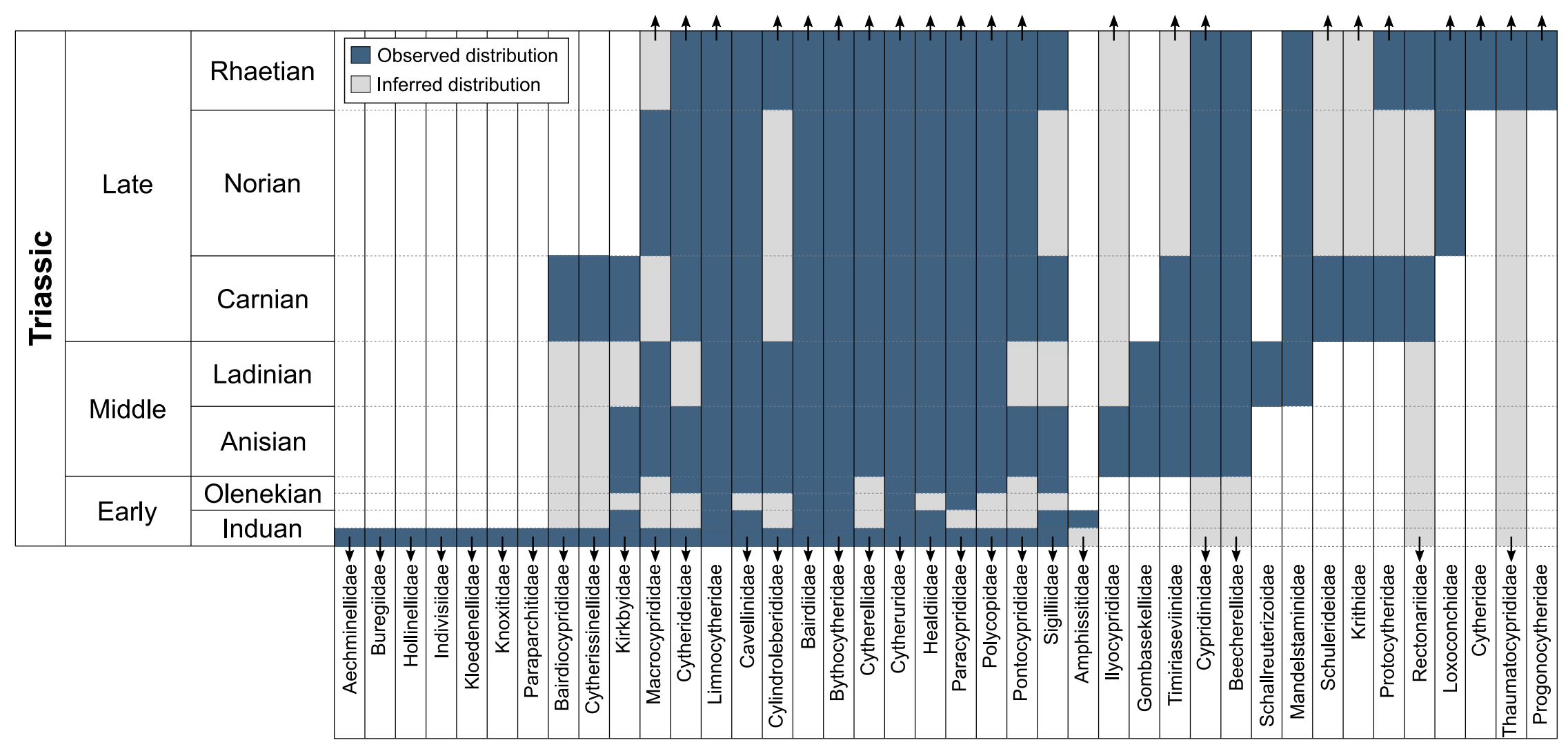




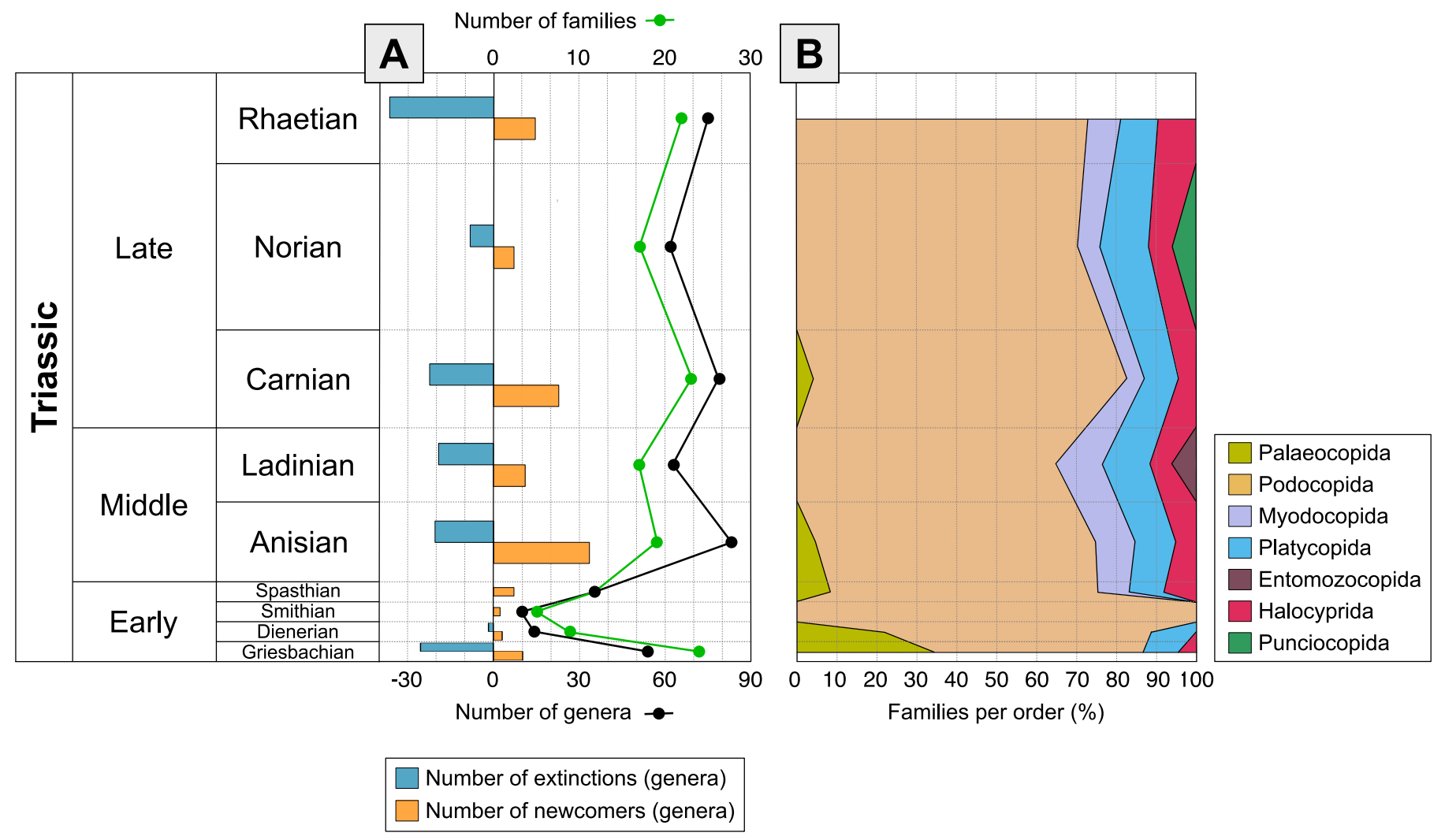




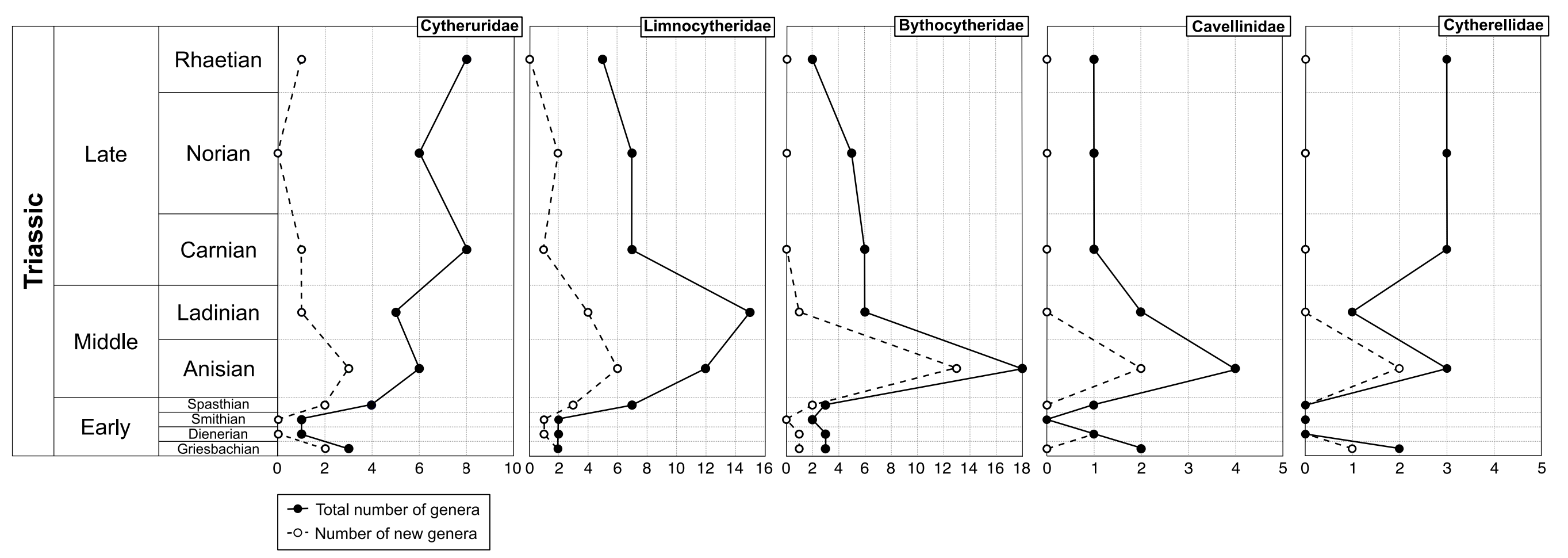




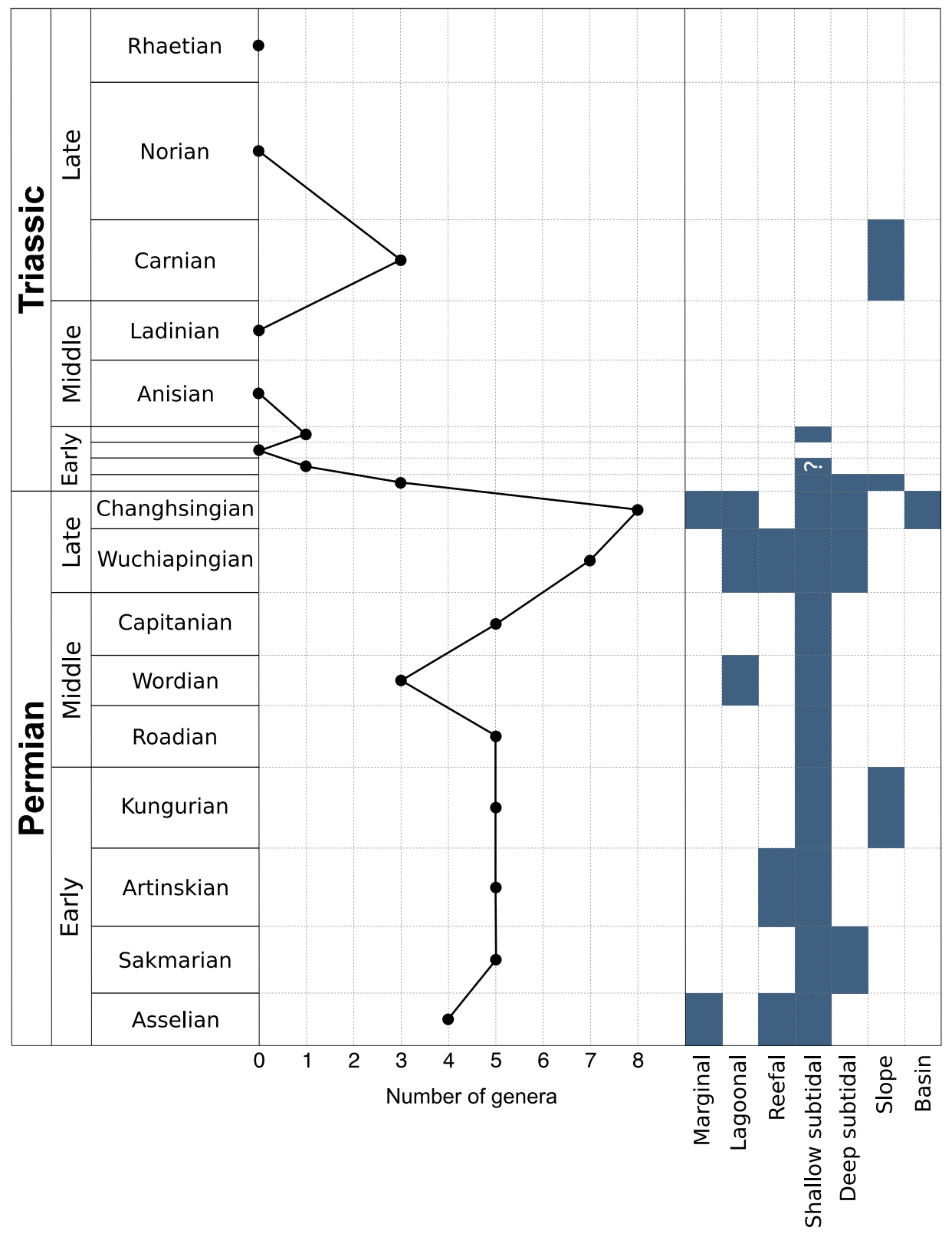




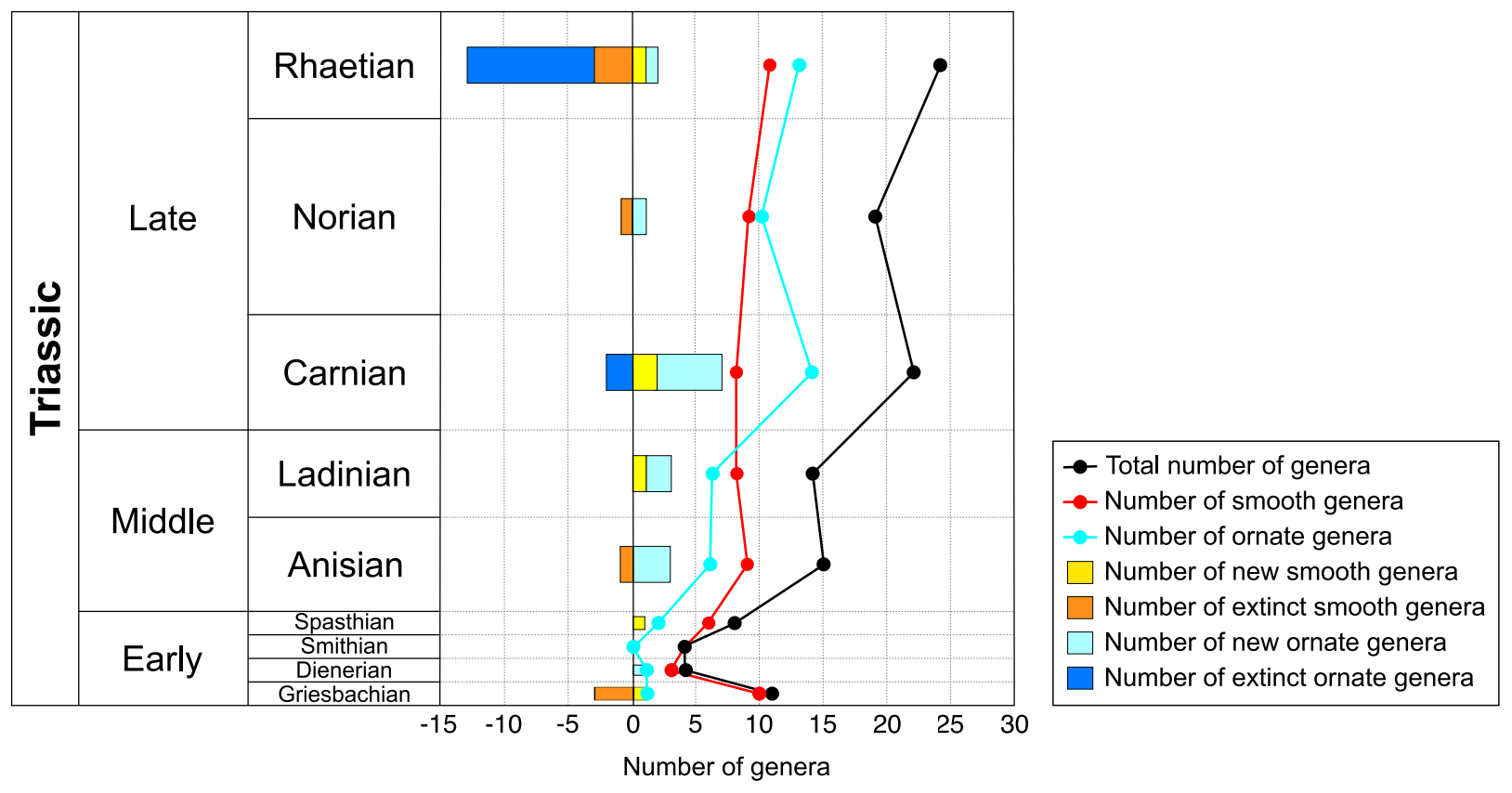




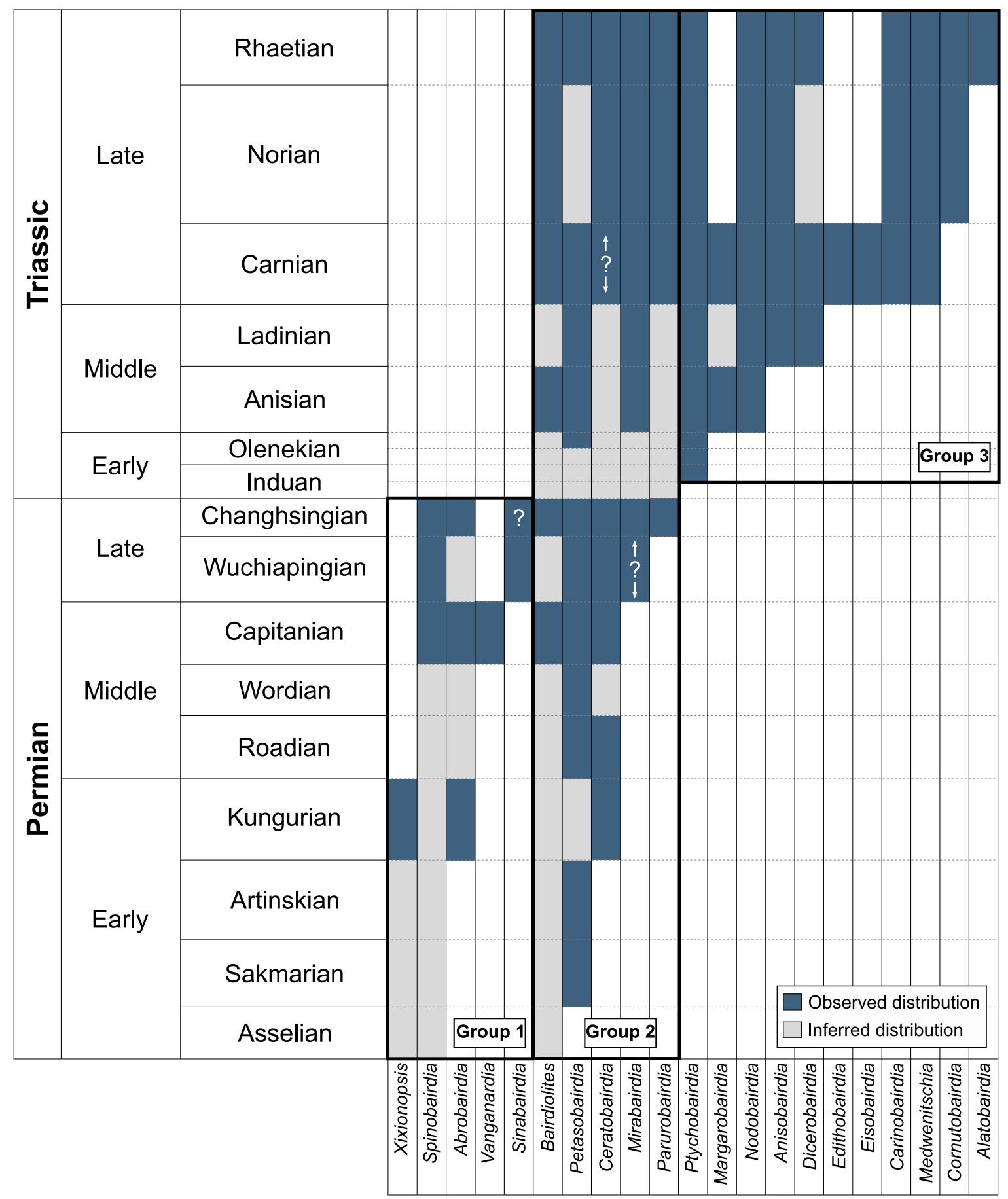




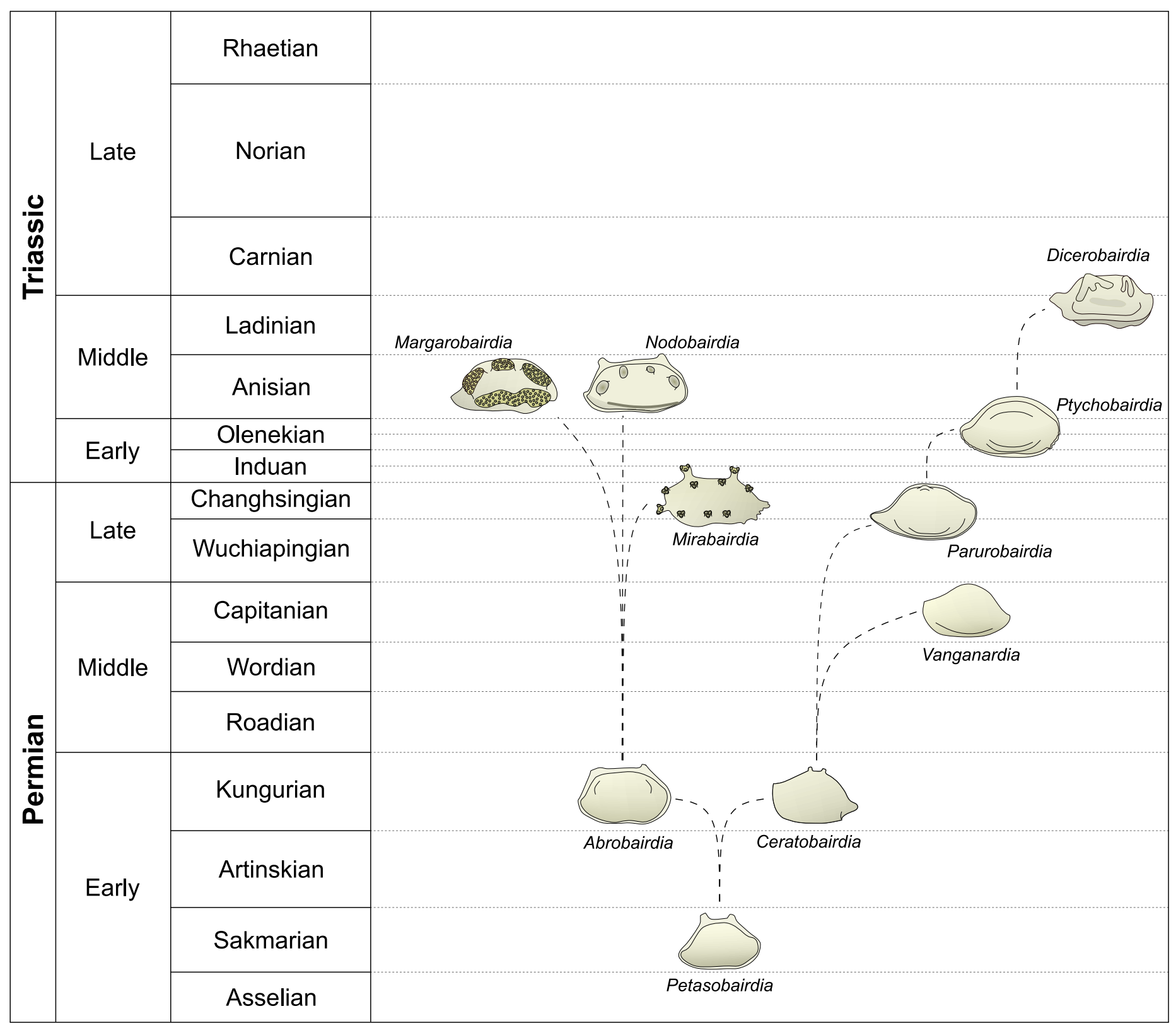




\section{Declaration of interests}

प The authors declare that they have no known competing financial interests or personal relationships that could have appeared to influence the work reported in this paper.

? The authors declare the following financial interests/personal relationships which may be considered as potential competing interests:

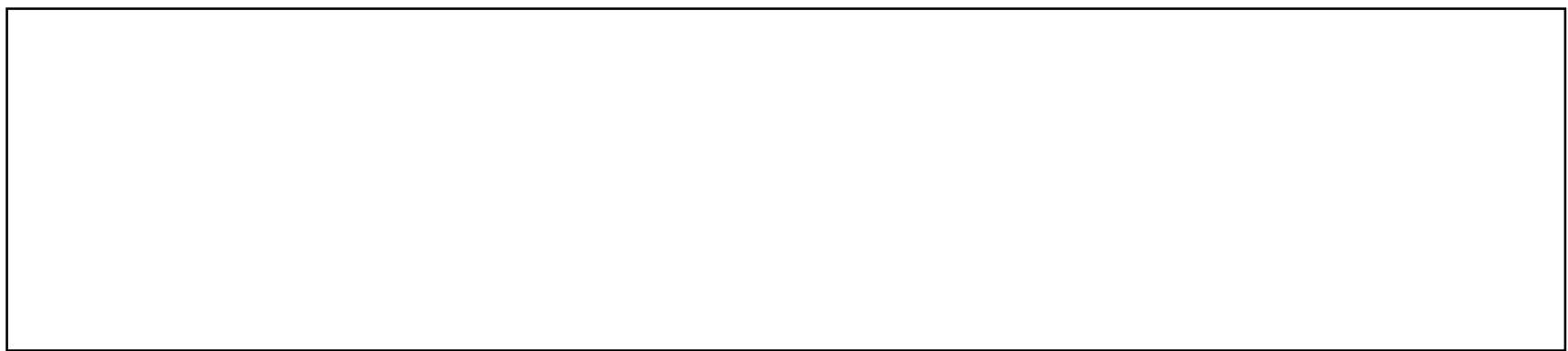

